
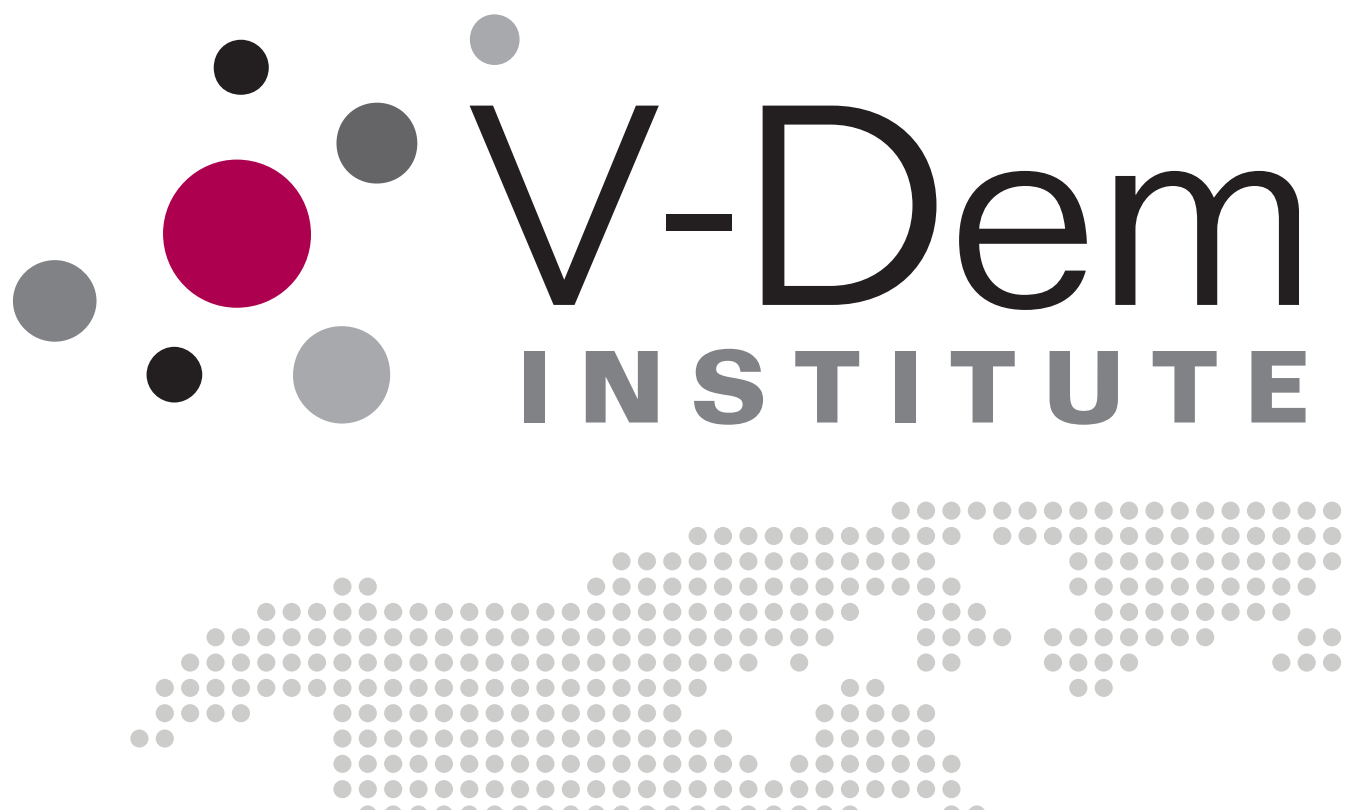 100900
100

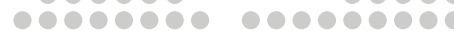

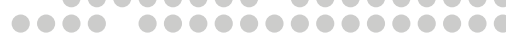

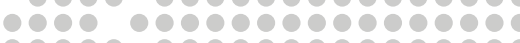

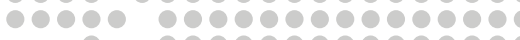
00

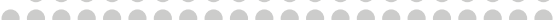

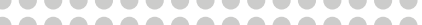

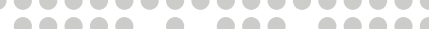

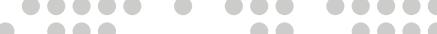
ror

The Autocratic Trust Bias: Politically Sensitive Survey Items and Self-censorship

Marcus Tannenberg

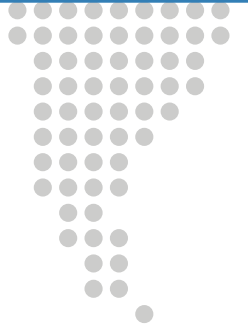

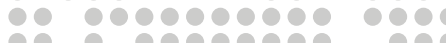

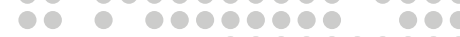

0000000000

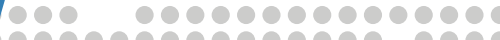

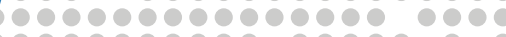

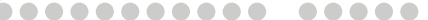

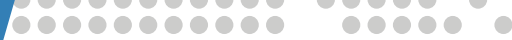

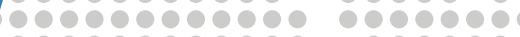

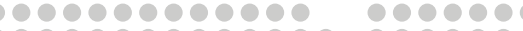
P0000000000000 000000

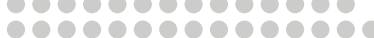
10000000000000000000 100000000000000000000 100000000000000000

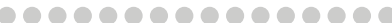
90000000000000

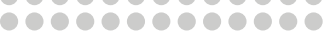

0000000000

00000000000

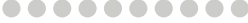

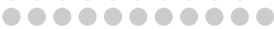

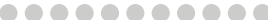
-

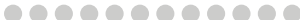
opopopopor 100000000 10000000

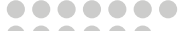

000000 000 100 웅 :

.

-

10 
Varieties of Democracy ( $\mathbf{V}-\mathbf{D e m})$ is a new approach to conceptualization and measurement of democracy. It is co-hosted by the University of Gothenburg and University of Notre Dame. With a V-Dem Institute at University of Gothenburg with almost ten staff, and a project team across the world with four Principal Investigators, fifteen Project Managers (PMs), 30+ Regional Managers, 170 Country Coordinators, Research Assistants, and 2,500 Country Experts, the V-Dem project is one of the largest ever social science research-oriented data collection programs.

Please address comments and/or queries for information to:

V-Dem Institute

Department of Political Science

University of Gothenburg

Sprängkullsgatan 19, PO Box 711

SE 40530 Gothenburg

Sweden

E-mail: contact@v-dem.net

V-Dem Working Papers are available in electronic format at www.v-dem.net. Copyright (C2017 by authors. All rights reserved. 


\title{
The Autocratic Trust Bias: Politically Sensitive Survey Items and Self-censorship*
}

\author{
Marcus Tannenberg
}

${ }^{*}$ I am grateful to Staffan I. Lindberg, Ellen Lust, Beth Simmons, Anja Neundorf, Mattias Agerberg and participants of the $2017 \mathrm{~V}$-Dem Research Conference for valuable comments and suggestions. This research project was supported by Riksbankens Jubileumsfond, Grant M13-0559:1, PI: Staffan I. Lindberg, V-Dem Institute, University of Gothenburg, Sweden; by Knut and Alice Wallenberg Foundation to Wallenberg Academy Fellow Staffan I. Lindberg, Grant 2013.0166, V-Dem Institute, University of Gothenburg, Sweden; by European Research Council, Grant 724191, PI: Staffan I. Lindberg, V-Dem Institute, University of Gothenburg, Sweden; by the Swedish Research Council, Grant 439-2014-38, PI: Pam Fredman, ViceChancellor, University of Gothenburg, Sweden; as well as by internal grants from the Vice-Chancellor's office, the Dean of the College of Social Sciences, and the Department of Political Science at University of Gothenburg. We performed simulations and other computational tasks using resources provided by the Swedish National Infrastructure for Computing (SNIC) at the National Supercomputer Center in Sweden, SNIC 2016/1-382 and 2017/1-68. We specifically acknowledge the assistance of In-Saeng Suh at CRC and Johan Raber at SNIC in facilitating our use of their respective systems. 


\section{Abstract}

Because of the perceived risk of repression some survey questions are likely sensitive in more autocratic countries while less so in more democratic countries. Yet, survey data on potentially sensitive topics are frequently used in comparative research despite concerns about comparability. In a novel approach to test the comparability of politically sensitive questions I employ a multilevel-analysis with more than 80000 respondents in 36 African countries to test for systematic bias when the survey respondents believe (fear) that the government has commissioned the survey, as opposed to an independent research institute. The findings indicate that fear of the government induces a substantial and significant bias on questions regarding the citizen-state relationship in more autocratic countries, but not in more democratic countries. This has practical implications for the comparative use of survey data. 


\section{Introduction}

When Guineans were asked how much they trust president Alpha Condé in 2013, on average 45 percent said - "A lot". This is considered strong approval by most accounts, but is it true? When respondents are divided into two groups, one that believes that the interviewer was sent by the government and and one that does not, we get a different picture. Of the former 56 percent indicated "A lot" of trust in Condé, while in the latter group only 31 percent shared this sentiment. In contrast, in highly democratic Ghana the difference between these two groups of respondents is only 4 percent, compared to 25 percent in considerably less democratic Guinea ${ }^{1}$. There seems to be something going on here with respect to perceived survey sponsor and the regime respondents live in.

It is well known that respondents tend to give untruthful answers to sensitive survey questions due to "social desirability bias". If your true opinion deviates from a strong societal norm, it can be socially desirable for the respondent to misreport their true opinions or preferences regarding sensitive issues such as sexuality, race, or income (Tourangeau and Yan, 2007). In autocratic countries an additional set of questions are sensitive for reasons beyond privacy and social adaption. In particular, questions regarding the citizens' relation with, and their attitudes towards the authorities. In addition to the social desirability not to deviate from norms, respondents subjected to autocratic rule practice "preference falsification" to align their answers with the perceived wishes of the regime (Kuran, 1997). Given that authoritarian regimes often pay close attention to what their citizens do and say in order to sanction those who challenge the official discourse (Linz, 2000), there is a real risk that citizens associate public opinion surveys with government intelligence gathering. Citizens can therefore be expected to appease the regime with their responses out of fear that failure to do so may result in repression, physical or otherwise. In electoral systems dominated by patronage politics, voters who fail to show their political support for the government may fear, not outright repression, but being excluded from patronage networks and expected benefits (Bratton, Bhavnani, and Chen, 2012). To the extent that citizens practice self-censorship in any form, and that the prevalence of this depend on the perceived risk of repression or exclusion, responses on sensitive issues are systematically biased across countries and are therefore not comparable between countries where the perceived risks differs.

Yet despite this, scholars conduct comparative studies of both the causes, and effects of,

\footnotetext{
${ }^{1}$ The results summarized in this paragraph are drawn from the Afrobarometer survey round 5 (www.afrobarometer.org)
} 
for example, trust in government, democratic attitudes, regime support or political legitimacy across countries with varying regime types (cf. Gilley (2006b), Gilley (2006a), Booth and Seligson (2009) and Moehler (2009)), where they rely on data derived through direct questions on these (in some countries, but not in others) potentially sensitive topics. Others

simply omit suspicious outliers from their samples such as China and Vietnam where some 90 percent of respondents trust the national government "quite a lot" or a "great deal" (AsianBarometer, 2008). This, however, restricts academic inquiry regarding trust in the government to democracies and low-trust autocracies. It is difficult to say which approach is the least problematic.

In order to test the the extent to which citizens practice self-censorship when responding to surveys in countries where citizens' experience different perceived (and real) risks of repression, I compare responses to potentially sensitive questions from more than 80 thousand respondents across 33 to 36 African countries, testing the interaction effect of respondents belief about the survey sponsor with the level of democracy in the respondents country, in a multilevel design. The results indicate that questions relating to the citizen-state relationship, such as "Trust in the President or Prime Minister" or if you think democracy is a "preferable system" are systematically biased with the level of democracy in the country, while apolitical questions, such as "How much do you trust your neighbors?", are not. Thus caution is warranted for employing the former types of survey items in comparative studies when comparing different regime types (without using reliability weights), but not for the latter.

\section{Self-censorship and how estimate it}

Survey respondents can feel the need to censor their responses if (a) it is invasive into private matters such as sexuality or personal income; or (b) it elicit responses that can be socially undesirable or politically incorrect; or (c) the respondent fear that their response can have consequences if disclosed (Tourangeau and Yan, 2007). As a result questions relating to, for example, income (Chung and Monroe, 2003), voter turnout (Holbrook and Krosnick, 2010), prejudice against other ethnic or religious groups (Kuklinski, Cobb, and Gilens, 1997), and drug abuse or other illegal activities (Krumpal, 2013), can cause the respondent to hide the truth out of (a) prestige; (b) fear of social sanctioning from peers; and (c) fear of punishment. This can lead to high rates of systematic non-responses and/or biased answers, resulting in poor data. While (a) and (b) induce social desirability bias in surveys conducted in both democratic and autocratic regimes alike, (c) is of greater concern in autocratic and semi- 
autocratic contexts, where the perceived risk of repression is likely to be higher. Indeed, it has been argued that citizens subjected to authoritarian rule have strong incentives to practice "preference falsification" (Kuran, 1997), and Schedler (1999) raises concerns about the possibility of obtaining reliable measures of regime legitimacy through representative public-opinion surveys or qualitative interviews in autocracies because of the opaque and repressive features of those regimes. Fear of repression for failing to give the - from the regime's point of view - desired answer is expected to have an effect on the responses, especially when respondents are uncertain about their anonymity.

So what does this mean for cross-country comparative studies if we are interested in, for example, approval ratings, regime support or the legitimacy of the regime attributed by citizens? If the levels of self-censorship are more or less equal across countries on the proxies or components of said question or indexes, the issue is less problematic. We would simply have to deal with either inflated or deflated numbers across the board. However, if the propensity to self-censor depends on some traits that are heterogeneous across countries, such as the level of democracy or political repression, the size of the bias differs between countries, and thus restricts the possibility of comparative analysis. In a comparative study of political approval rating in 128 countries, Guriev and Treisman (2016) make an effort to account for the influence of fear by including repression in their analysis and controlling for if leaders receive higher ratings during years of increased repression. While they find no clear relationship between repression and approval, I would expect the effects of repression to be long lasting, especially in the absence of a regime transition. A 9 year panel may simply be to short to pick up a variation in these effects. Furthermore if a regime is prepared to use political repression at $\mathrm{t}=1$, unless there has been major political changes, it is likely that respondents already anticipate this at $\mathrm{t}=0$.

Some recent findings warrants caution for the reliability of survey responses in repressive and non-democratic settings. A recent study by Garcia-Ponce and Pasquale (2015) in Zimbabwe - where government repression and insecurity is commonplace - indicates that an upward bias of survey respondents' reported level of trust in the president and the ruling party, is affected by recent experience of state-led repression. Respondents who had experienced state-led violence up to 30 days prior to being interviewed were more likely to believe that the state had commissioned the survey (Garcia-Ponce and Pasquale, 2015). While this suggests that a recent reminder of the regimes repressive nature will lead to inflated levels of reported trust, it is reasonable to believe that citizens do not easily forget what kind of regime they are subjected to and should therefore falsify their preferences (perhaps to 
a lesser degree) even if they have not experienced state sponsored violence recently. Frye et al. (2017) employ a series of list experiments and find actual approval ratings of Russia's president Vladimir Putin shy of 10 percentage points below those received through direct questioning. Also using a list experiment Kalinin (2014) finds that Russians' electoral support for Putin is inflated with about 20 percentage points. While these results show that approval of Putin was still staggeringly high, respondents do indeed inflate their approval in autocratic Russia. In the Chinese context, Jiang and Yang (2016) show the increase in preference falsification in the aftermath of a major political purge in Shanghai.

Does this mean that we cannot trust citizens' trust in government or their political preferences in general? To answer this questions we need to move away for single-country case studies and test for a systematic bias across a larger sample of countries. To test for response bias due to perceived fear of the government I turn to Afrobarometer data and specifically the the very last question in the Afrobarometer that asks "By the way, who do you think sent us to do this interview?" ". Despite that the enumerators conducting the survey introduces themselves as affiliated with "an independent research organization" which does not "represent the government or any political party", in the 5th round of the Afrobarometer only 29 percent of the respondents considered the survey to be independent, 15 percent stated that they did not know and the remaining 56 percent believed that the survey was sponsored by the government. With the help of this survey question I divide respondents in to three groups: non-suspecting (those that believe the survey to be independent); suspecting (those that believe the government to sponsor the survey); and a don't know group. This questions has been featured as a proxy for the "costliness of dissent" or "fear of the government" in models predicting vote choice in 16 African countries (Bratton, Bhavnani, and Chen, 2012) and voting intentions in Zimbabwe (Bratton and Masunungure, 2012). In contrast to these authors I argue that the propensity to suspect the government as sponsor of the survey in one country is not very informative or a good proxy for political fear in that country. This is illustrated by the fact that in the most democratic and the most autocratic countries in the 2012 sample, Cape Verde and Sudan, virtually the same percentage of respondents (46-47) believed the government to sponsor the survey. In the full sample of 36 countries, suspecting the government as survey sponsor is only correlated with the country's level of democracy at .11 level. It is clear that this variable in of itself is a poor proxy for costliness of dissent. Instead beliefs about survey sponsorship should have an impact only to the extent that the respondents also fear punishment from the authorities. Studying the anomaly of Ethiopians'

\footnotetext{
${ }^{2}$ I am not aware of any other survey that includes a similar question which is why I have only been able to test my proposition in the African context
} 
views of democracy Mattes and Teka (2016, p. 31) note the surprising fact that respondents who believed the state to be have ordered the survey were "less likely to state that they feared speaking their mind about politics". This does, however, make sense considering that the very question about whether or not one must be careful of what you say about politics is potentially a sensitive question itself.

In sum, suspicion of the survey sponsor should lead to preference falsification on potentially sensitive topics, but not so on questions that are apolitical in nature. If you falsify your preferences out of fear of the regime, you should be more likely to do so when you believe the regime will learn what you say. Following the same reasoning it may increase "Don't know" answers on sensitive issues but should not increase refusal and drop out rates as the latter is too blatant non-compliance ${ }^{3}$. From this I derive the following hypotheses:

- H1: Respondents who believe the government is behind the survey will answer differently on politically sensitive questions, compared to citizens who believe the survey to be independent

- H1.1: this is more prevalent in more autocratic countries and less so in democratic countries

- H2: Respondents who believe the government is behind the survey will not answer differently on non-sensitive questions, compared to citizens who believe the survey to be independent

To get an indication if this is taking place I analyze respondents propensity to state that they have high trust in their country's key leader (a) if they believed (feared) that the survey was conducted on behalf of the government, did not know, or that it was indeed carried out by a independent research institute, and (b) the level of democracy in their country. The level of democracy functions as a proxy of the "fear of government" mechanisms theorized to induce self-censorship. Using more than 80 thousands observations in 34 to 36 countries for two survey rounds, I employ multilevel logistical regressions with a set of control variables on the country and individual level.

It should be noted that although the design can tell us something about the variation in the level of self-censorship, a caveat is that it does not allow us to estimate the absolute

\footnotetext{
${ }^{3}$ In the Lebanese context Corstange (2014) shows that foreign sponsorship substantively increase both refusal and drop out rates compared to university sponsorship
} 
level of self-censorship at hand. There is the risk that even among respondents that believe that the survey truly is independent, self-censorship is taking place. They may still be wary that the authorities can use the survey to trace unsanctioned opinions to an individual, a neighborhood or a village. To the extent that respondents adopt a better-safe-than-sorryapproach the overall response bias will be larger. This would reduce the between group effects. Thus the results reported in this paper are despite this built-in downward bias in my estimates. Bearing in mind that the absolute levels of response bias cannot be established, the findings do show that between-group differences are clear and meaningful.

Moreover, the research design does not allow me to determine whether the effects I find stem from bias caused by believing that the government has sent the enumerator or that the bias is caused by believing that the enumerator is from an independent organization, or from a combination of the two. While I have strong theoretical reasons to suspect that the bias stem form the former, especially for questions evaluating the regime, my empirical strategy offers no leverage to separate these two effects. Questions relating to economic well-being, access to food, etc. could, for example, suffer from bias caused by the respondents' belief that an independent organization is more likely to be connected with development aid and that reporting hardship will induce aid flows.

\section{$3 \quad$ Data and results}

In this section I briefly describe the data and present my results. Individual level data is taken from the Afrobarometer's 5th and 6th round (Afrobarometer, 2016). The surveys were conducted from 20.10.11 to 04.06.13 and 01.03.14 to 22.11.15. I match the data with country level data for 2012 and 2014 from the Varieties of Democracy Dataset (Coppedge et al., 2017b). I first and foremost base my analysis on data from the 5th and 6th round of the Afrobarometer because those rounds allow for the highest number of respondents across the highest number or countries, with more than 40 thousand respondents nested in 34 and 36 countries respectively. The Afrobarometer have included the question regarding perceived survey sponsor since its 2nd round, but previous rounds cover fewer countries. However, as a robustness check I merge Afrobarometer rounds 2, 3, 4, 5 and 6, and match them with V-Dem data for 2003, 2005, 2008, 2012 and 2014 respectively (see Appendix A, table 7). This full dataset provides more than 160 thousand respondents nested in 124 country years.

\section{Dependent variables}


- Most sensitive DVs - Trust key leadership figure; Trust ruling party; Preference for democracy; Perception of corruption in President/PM office

- Somewhat sensitive DVs - Trust the police; Country moving in right direction; Perception of corruption in taxation agency

- Non-sensitive DV - Trust in neighbors

For the first dependent variables regarding trust in various authorities respondents indicating "Not at all" or "Just a little" or "I trust them somewhat" are coded as 0, and "I trust them a lot" are coded as 1. First this allows for a clear binary logit regression instead of a ordnial logit. Moreover, I theorize that preference falsification (may) occur in this binary divide. If you are in the business of falsifying your preferences you are likely looking for the safest possible option. I acknowledge that is possible that stating that you trust the president "somewhat" or "a lot" are safe enough in most environments, whereas "Not at all" or "Just a little" might be sensitive in some circumstances. I therefore replicate all model specifications using this binary divide (see Appendix A, table 9). For the variables regarding how many in the presidents office/tax authorities the respondent believes are corrupt, respondents indicating "All of them" or "most of them" are coded as 1, and "some of them" and "none" are coded as 0. For preference for democracy, respondents indicating that "Democracy is preferable to any other kind of government" are coded as 1, and "In some circumstances, a non-democratic government can be preferable" or "For someone like me, it doesnt matter what kind of government we have" are coded as 0. For the non-sensitive dependent variable trusting your neighbor, "Not at all" or "Just a little" are coded as 0, and "I trust them somewhat" and "I trust them a lot" are coded as 1.

\section{Independent variables}

The main independent variable "Survey Sponsor" is generated from the questions item "Just one more question: Who do you think sent us to do this interview?" where respondents who indicate that they believe the enumerator was sent by the local, regional or national Government, or any of its agencies are coded as 1. Respondents who believed the survey to be commissioned by a Non Governmental Organization (NGO), an University, a research company etc. was coded as 0 . Of the complete sample 54 percent of respondents reported that they believed that the government was behind the survey, and 30 percent believed it to be independent. 16 percent of respondents reported that they did not know. The latter group of respondents are excluded in the main analysis but are coded as 1 together with the "suspecting" group in robustness check of all model specifications (see Annex A, table 7 and 
8). The rational being that not knowing who the sponsor is likely also induce preference falsification in repressive settings, albeit to a lesser degree than suspecting the government. The variance of suspecting the government as sponsor at a country level is between 30 percent in Egypt and 75 percent in South Africa producing sufficiently large number of respondents in each category and country for analysis. Moreover this variation only correlates with the level of democracy at .10 level.

In all model specifications I control for the following set of commonly used individual level control variables (cf. Adida et al. (2016), Carlson (2014) and Moehler and Lindberg (2009)): age; gender; education level; how often one discuss politics; and for urban/rural residency. I purposely do not include variables which in and of themselves are sensitive items. Whether you believe the country is "moving in the right or wrong direction", may indeed predict whether you trust the key leadership figure, but it may also provoke self-censorship. Likewise the item "In your opinion, how often, in this country: do people have to be careful of what they say about politics?" would offer a direct test for respondents fear, were it not for that those that truly are fearful and that believe that the government sponsor the survey will not answer truthfully on either item. In addition to theoretically justifying the exclusion of politically sensitive items as predictors in my model specifications I run two models with the above mentioned items as dependent variables. The results show that indeed both are associated with similar bias as the main dependent variables, further motivating their exclusion.

\section{Country level}

As a proxy for the perceived risk of repression at the country level I employ the Varieties of Democracy's Electoral Democracy Index (Teorell et al., 2016; Coppedge et al., 2017b). It's an aggregated index building on more than 30 fine grained sub components of: freedom of expression and association; suffrage; elections quality; and the election of the chief executive (see Coppedge et al. (2017a), Coppedge et al. (2017c), Marquardt and Pemstein (2017), and Pemstein et al. (2017) for more detail). The rationale for using a highly aggregated index of the level of democracy is to be able to test if existing studies that draw conclusions from comparative survey data from countries at a vastly different levels of democracy are suffering from biases or not (cf. Gilley (2006a), Moehler and Lindberg (2009)). Arguably an aggre-

gated measure may be a crude proxy for a perceived risk of repression. I therefore employ an index of freedom from political killings and torture by the government (Coppedge et al., 2017a), in additional model specifications. Both indexes are continuous measures ranging from 0 to 1, where 1 corresponds a to a perfect Electoral Democracy, and full physical in- 
tegrity respectively.

In addition I also control for the the logged level of GDP per capita and corruption at the country level which have been shown to predict several of the dependent variables (cf. (Rothstein, 2011) and (Boräng, Nistotskaya, and Xezonakis, 2017)). Data of GDP per capita is taken from UN Statistics (2016). The level of corruption is an index of political corruption comprised of expert assessments of the pervasiveness of corruption in the executive, the legislature, the public sector and the judiciary (McMann et al., 2016; Coppedge et al., 2017a). The index is continuous and ranges from 0 to 1 , where 0 no corruption and 1 complete corruption.

Table 1: Summary statistics

\begin{tabular}{lccccc}
\hline \hline Statistic & $\mathrm{N}$ & Mean & St. Dev. & Min & Max \\
\hline sponsor (government) & 155,425 & 0.620 & 0.485 & 0 & 1 \\
sponsor (government+don't know) & 183,332 & 0.678 & 0.467 & 0 & 1 \\
trust leader & 177,392 & 0.365 & 0.482 & 0 & 1 \\
trust police & 180,688 & 0.255 & 0.436 & 0 & 1 \\
trust ruling party & 171,692 & 0.261 & 0.439 & 0 & 1 \\
trust neighbor & 52,576 & 0.623 & 0.485 & 0 & 1 \\
country right direction & 130,064 & 0.516 & 0.500 & 0 & 1 \\
corruption president & 131,777 & 0.322 & 0.467 & 0 & 1 \\
corruption tax agency & 135,946 & 0.434 & 0.496 & 0 & 1 \\
prefer democracy & 185,332 & 0.673 & 0.469 & 0 & 1 \\
rural & 185,332 & 0.610 & 0.488 & 0 & 1 \\
female & 185,332 & 0.501 & 0.500 & 0 & 1 \\
discuss politics & 183,339 & 0.883 & 0.719 & 0 & 2 \\
education & 185,327 & 3.284 & 2.129 & 0 & 9 \\
age & 183,319 & 36.851 & 14.597 & 18 & 105 \\
gdp pc & 124 & 7.049 & 0.978 & 5.438 & 9.242 \\
electoral democracy & 124 & 0.536 & 0.173 & 0.129 & 0.853 \\
physical integrity & 124 & 0.663 & 0.219 & 0.055 & 0.968 \\
corruption & 124 & 0.503 & 0.072 & 0.294 & 0.634 \\
\hline
\end{tabular}


Because respondents are not randomly distributed but clustered within countries, I employ a multilevel model which takes these data hierarchies into account and allows testing the effect of a two-level interaction between survey sponsor (individual level) and level of democracy (country level). The model is a logistic random slope model. The specification of the baseline multilevel model is as follows:

$$
y_{i c}=\gamma_{00}+\gamma_{1} \text { dem }_{c}+\gamma_{2} \text { sponsor }_{i c}+X_{i c}^{\prime} \lambda+Z_{c}^{\prime} \delta+U_{0 c}+R_{1 c}+\eta_{i c}
$$

And adding the two level interaction term between individual level suspicion of survey sponsor and country-level democracy we get the full multilevel model specification (see Aguinis, Gottfredson, and Culpepper (2013)):

$$
y_{i c}=\gamma_{00}+\gamma_{1} \text { dem }_{c}+\gamma_{2} \text { sponsor }_{i c}+\gamma_{3}\left(\text { dem }_{c} \text { x sponsor } i c\right)+X_{i c}^{\prime} \lambda+Z_{c}^{\prime} \delta+U_{0 c}+R_{1 c}+\eta_{i c}
$$

Where $y_{i c}$ is the dependent variable for individual $i$ in country $c, \gamma_{00}$ is the average individual level intercept, dem $_{c}$ is the country-level democracy, sponsor ${ }_{i c}$ is an individual's perception of survey sponsor, $X_{i c}^{\prime}$ and $Z_{c}^{\prime}$ are vectors of individual and country-level controls, $U_{0 c}$ is the intercept variance, $R_{1 c}$ is the slope variance (for sponsor $r_{i c}$ ), and $\eta_{i c}$ is the

individual-level error term. I do not discuss nor present the slope and intercept variance in the main text and tables. In short, the slope and intercept variance is reduced when introducing the two-level interaction, i.e. it explains some of the between country variance (for details please seeAppendix A table 5).

Because multilevel logistic regression coefficients are somewhat difficult to interpret (even without two-level interaction terms) I proceed by graphing the interaction effects (Brambor, Clark, and Golder, 2006), and then by visualizing the effects in each country expressed in odds ratios.

\subsection{Results}

Table 2 summarizes the regression results from 7 generalized linear mixed models (GLMM) for 6 different dependent variables for the 5th round of the Afrobarometer. The baseline (model 1) is a generalized linear mixed model testing the effects of the individual level predictors and the country level predictors on the propensity to indicate "A lot" of trust in the country's key leadership figure. In the full sample the strongest individual predictor is 
believing the government to be behind the survey, followed by rural residency. Higher age is associated with higher trust in the president or prime minister, while higher education exhibit a negative relationship. Discussing politics more frequently is associated with higher trust. In contrast to what we see in Western Europe and North America, females are less likely than males to trust the key leader, the police, the ruling party and also their their neighbors. On the country level higher corruption is associated with lower trust. Introducing the cross level interaction (model 2) does not substantively change the magnitude or direction of any control variables outside of the interaction. The direction and significance of the interaction term supports the hypothesis that respondents who believe the government to sponsor the survey will inflate their answer on a politically sensitive question like trust in the president or prime minister. This effect is large in countries at low levels of Electoral Democracy, and decreases with higher democracy scores. Substituting the dependent variable with trust in the police (model 3) and trust in the ruling party (model 4) corroborates that questions relating to the regime and its performance suffer from systematic response bias across regime types. While the interaction effect does not show as significant in model 3 in the regression table there is still a significant effect at lower levels of democracy which is vizualized in the interaction graph in figure 2 below. Likewise, respondents are less likely to indicate that they prefer democracy when they believe the survey is sponsored by the government and when they live in a autocratic country (see figure 4). Note that in contrast to model 1, 2 and 3 these models include Swaziland, where the item trust in key leadership and ruling party is not asked. Model 6 show that respondents who believe the government sponsor the survey are less likely to state that "most" or "all" in the presidents or prime minister office are corrupt. The interaction effect is not significant across the board but again we see a smaller or no effect at higher levels of democracy (see figure 5. In model 7 the sensitive dependent variable is replaced by the non-sensitive item "Trust in Neighbors". In line with my expectations the two groups of respondents do not answer systematically different on non-sensitive questions, and there is no relationship with the level of Electoral Democracy.

Testing the same relationships using the 6th round of the Afrobarometer Table 3 summarizes the regression results from 7 generalized linear mixed models (GLMM). We note few differences other than minor changes in the magnitude of the effect, eg. the bias is somewhat smaller for trust in the leader but larger for perception of corruption in the leader's office. As trust in neighbors was not asked in the 6th round I instead employ perceptions of corruption among tax officials. As expected this is less (in fact not at all) sensitive than corruption in the president's or prime minister's office. 
These results are robust to if the dependent variables are coded "Not at all" or "Just a little" as 0 , and "I trust them somewhat" or "I trust them a lot" are coded as 1 (see Appendix A, table 9). Furthermore, re-coding the main independent variable so that respondents who "Do not know" who commissioned the survey are collapsed with those who believed it was the government do not change the results (see Appendix A, table 7 and 8). The results also hold when when the models are run using full data set, with more than 140 thousand respondents across 124 country years (see Appendix A, table 6). It should be noted that when changing the the level two unit of analysis from country to country years, the level two units are no longer independent and some countries are only represented by 1 country year while others are represented by 5 country years.

In an attempt to tease out which aspects of non democracies that induce bias on politically sensitive questions, table 4 show all models from table 2 reproduced with the Electoral Democracy Index substituted with an index of Physical Integrity. The pattern is almost identical and shows how the propensity to indicate high trust on sensitive questions decrease as a function of the freedom from torture and political killings, when the respondent believe that the survey is administrated by the authorities. And again there is no effect with respects to respondents' stated trust in their neighbors. 
Table 2: GLMM Regression Results Round 5

\begin{tabular}{|c|c|c|c|c|c|c|c|}
\hline & \multicolumn{7}{|c|}{ Dependent variable: } \\
\hline & \multicolumn{2}{|c|}{ trust leader } & \multirow{2}{*}{$\begin{array}{c}\text { trust police } \\
\text { (3) }\end{array}$} & \multirow{2}{*}{$\begin{array}{l}\text { trust rparty } \\
\text { (4) }\end{array}$} & \multirow{2}{*}{$\begin{array}{c}\text { dem pref } \\
(5)\end{array}$} & \multirow{2}{*}{$\begin{array}{c}\text { corr pres } \\
(6)\end{array}$} & \multirow{2}{*}{$\begin{array}{l}\text { trust neighb } \\
\text { (7) }\end{array}$} \\
\hline & (1) & (2) & & & & & \\
\hline sponsor & $\begin{array}{c}0.325^{* * *} \\
(0.057)\end{array}$ & $\begin{array}{c}0.735^{* * *} \\
(0.171)\end{array}$ & $\begin{array}{l}0.462^{* *} \\
(0.181)\end{array}$ & $\begin{array}{c}0.646^{* * *} \\
(0.202)\end{array}$ & $\begin{array}{c}-0.426^{* * *} \\
(0.142)\end{array}$ & $\begin{array}{c}-0.347^{* *} \\
(0.147)\end{array}$ & $\begin{array}{c}0.119 \\
(0.109)\end{array}$ \\
\hline democracy & $\begin{array}{c}0.718 \\
(0.670)\end{array}$ & $\begin{array}{c}0.788 \\
(0.657)\end{array}$ & $\begin{array}{c}1.628^{* * *} \\
(0.583)\end{array}$ & $\begin{array}{c}1.993^{* * *} \\
(0.575)\end{array}$ & $\begin{array}{c}1.591^{* * *} \\
(0.536)\end{array}$ & $\begin{array}{l}-0.894 \\
(0.621)\end{array}$ & $\begin{array}{c}0.089 \\
(0.713)\end{array}$ \\
\hline gdp pc & $\begin{array}{l}-0.195 \\
(0.125)\end{array}$ & $\begin{array}{l}-0.200 \\
(0.126)\end{array}$ & $\begin{array}{c}-0.265^{* *} \\
(0.127)\end{array}$ & $\begin{array}{c}-0.392^{* * *} \\
(0.102)\end{array}$ & $\begin{array}{l}-0.131 \\
(0.085)\end{array}$ & $\begin{array}{l}-0.172 \\
(0.124)\end{array}$ & $\begin{array}{c}-0.273^{*} \\
(0.141)\end{array}$ \\
\hline corruption & $\begin{array}{c}-3.849^{* * *} \\
(1.442)\end{array}$ & $\begin{array}{c}-3.907^{* *} \\
(1.531)\end{array}$ & $\begin{array}{c}-5.000^{* * *} \\
(1.541)\end{array}$ & $\begin{array}{c}-5.760^{* * *} \\
(1.294)\end{array}$ & $\begin{array}{l}2.337^{* *} \\
(1.028)\end{array}$ & $\begin{array}{l}-0.227 \\
(1.484)\end{array}$ & $\begin{array}{c}0.470 \\
(1.655)\end{array}$ \\
\hline rural & $\begin{array}{c}0.241^{* * *} \\
(0.025)\end{array}$ & $\begin{array}{c}0.243^{* * *} \\
(0.025)\end{array}$ & $\begin{array}{c}0.271^{* * *} \\
(0.028)\end{array}$ & $\begin{array}{c}0.285^{* * *} \\
(0.029)\end{array}$ & $\begin{array}{c}0.004 \\
(0.026)\end{array}$ & $\begin{array}{c}-0.119^{* * *} \\
(0.027)\end{array}$ & $\begin{array}{c}0.318^{* * *} \\
(0.023)\end{array}$ \\
\hline age & $\begin{array}{c}0.007^{* * *} \\
(0.001)\end{array}$ & $\begin{array}{c}0.007^{* * *} \\
(0.001)\end{array}$ & $\begin{array}{c}0.004^{* * *} \\
(0.001)\end{array}$ & $\begin{array}{c}0.006^{* * *} \\
(0.001)\end{array}$ & $\begin{array}{c}0.005^{* * *} \\
(0.001)\end{array}$ & $\begin{array}{c}-0.002^{* *} \\
(0.001)\end{array}$ & $\begin{array}{c}0.008^{* * *} \\
(0.001)\end{array}$ \\
\hline education & $\begin{array}{c}-0.103^{* * *} \\
(0.006)\end{array}$ & $\begin{array}{c}-0.103^{* * *} \\
(0.006)\end{array}$ & $\begin{array}{c}-0.113^{* * *} \\
(0.007)\end{array}$ & $\begin{array}{c}-0.117^{* * *} \\
(0.007)\end{array}$ & $\begin{array}{c}0.093^{* * *} \\
(0.007)\end{array}$ & $\begin{array}{c}0.032^{* * *} \\
(0.007)\end{array}$ & $\begin{array}{c}-0.040^{* * *} \\
(0.006)\end{array}$ \\
\hline female & $\begin{array}{c}-0.090^{* * *} \\
(0.022)\end{array}$ & $\begin{array}{c}-0.090^{* * *} \\
(0.022)\end{array}$ & $\begin{array}{c}-0.082^{* * *} \\
(0.024)\end{array}$ & $\begin{array}{c}-0.061^{* *} \\
(0.025)\end{array}$ & $\begin{array}{c}-0.217^{* * *} \\
(0.023)\end{array}$ & $\begin{array}{l}-0.039 \\
(0.025)\end{array}$ & $\begin{array}{c}-0.118^{* * *} \\
(0.022)\end{array}$ \\
\hline discuss pol & $\begin{array}{c}0.046^{* * *} \\
(0.016)\end{array}$ & $\begin{array}{c}0.046^{* * *} \\
(0.016)\end{array}$ & $\begin{array}{c}-0.032^{*} \\
(0.017)\end{array}$ & $\begin{array}{c}0.108^{* * *} \\
(0.018)\end{array}$ & $\begin{array}{c}0.250^{* * *} \\
(0.017)\end{array}$ & $\begin{array}{c}0.096^{* * *} \\
(0.018)\end{array}$ & $\begin{array}{l}-0.003 \\
(0.016)\end{array}$ \\
\hline $\begin{array}{l}\text { sponsor* } \\
\text { democracy }\end{array}$ & & $\begin{array}{c}-0.774^{* *} \\
(0.309)\end{array}$ & $\begin{array}{l}-0.447 \\
(0.329)\end{array}$ & $\begin{array}{c}-0.646^{*} \\
(0.361)\end{array}$ & $\begin{array}{c}0.377 \\
(0.263)\end{array}$ & $\begin{array}{c}0.377 \\
(0.269)\end{array}$ & $\begin{array}{l}-0.108 \\
(0.202)\end{array}$ \\
\hline Constant & $\begin{array}{l}2.182^{*} \\
(1.299)\end{array}$ & $\begin{array}{l}2.210^{*} \\
(1.292)\end{array}$ & $\begin{array}{l}2.424^{*} \\
(1.427)\end{array}$ & $\begin{array}{c}3.188^{* * *} \\
(1.018)\end{array}$ & $\begin{array}{l}-0.490 \\
(0.892)\end{array}$ & $\begin{array}{c}0.896 \\
(1.289)\end{array}$ & $\begin{array}{c}0.181 \\
(0.393)\end{array}$ \\
\hline Individuals & 41,046 & 41,046 & 42,574 & 40,228 & 43,301 & 36,376 & 44,127 \\
\hline Countries & 33 & 33 & 34 & 33 & 34 & 33 & 34 \\
\hline Log Likeli. & $-24,679$ & $-24,676$ & $-21,785$ & $-20,545$ & $-23,440$ & $-21,008$ & $-26,535$ \\
\hline
\end{tabular}

Note: Robust standard errors in parentheses. ${ }^{*} \mathrm{p}<0.1 ;{ }^{* *} \mathrm{p}<0.05 ;{ }^{* * *} \mathrm{p}<0.01$ 
Table 3: GLMM Regression Results Round 6

\begin{tabular}{|c|c|c|c|c|c|c|c|}
\hline & \multicolumn{7}{|c|}{ Dependent variable: } \\
\hline & \multicolumn{2}{|c|}{ trust leader } & \multirow{2}{*}{$\begin{array}{c}\text { trust police } \\
\text { (3) }\end{array}$} & \multirow{2}{*}{$\begin{array}{l}\text { trust ruling } \\
\text { (4) }\end{array}$} & \multirow{2}{*}{$\begin{array}{c}\text { pres corr } \\
(5)\end{array}$} & \multirow{2}{*}{$\begin{array}{c}\operatorname{tax} \text { corr } \\
(6)\end{array}$} & \multirow{2}{*}{$\begin{array}{c}\text { prefer dem } \\
(7)\end{array}$} \\
\hline & (1) & (2) & & & & & \\
\hline sponsor & $\begin{array}{c}0.336^{* * *} \\
(0.056)\end{array}$ & $\begin{array}{c}0.560^{* * *} \\
(0.176)\end{array}$ & $\begin{array}{l}0.377^{* *} \\
(0.169)\end{array}$ & $\begin{array}{c}0.765^{* * *} \\
(0.230)\end{array}$ & $\begin{array}{c}-0.557^{* * *} \\
(0.177)\end{array}$ & $\begin{array}{l}-0.268 \\
(0.164)\end{array}$ & $\begin{array}{c}-0.337^{* *} \\
(0.133)\end{array}$ \\
\hline democracy & $\begin{array}{l}-0.564 \\
(0.615)\end{array}$ & $\begin{array}{l}-0.320 \\
(0.626)\end{array}$ & $\begin{array}{c}0.726 \\
(0.592)\end{array}$ & $\begin{array}{c}0.618 \\
(0.720)\end{array}$ & $\begin{array}{l}-0.770 \\
(0.638)\end{array}$ & $\begin{array}{l}-0.686 \\
(0.501)\end{array}$ & $\begin{array}{c}1.475^{* * *} \\
(0.552)\end{array}$ \\
\hline gdp pc & $\begin{array}{c}-0.206^{*} \\
(0.122)\end{array}$ & $\begin{array}{c}-0.207^{*} \\
(0.116)\end{array}$ & $\begin{array}{l}-0.117 \\
(0.106)\end{array}$ & $\begin{array}{l}-0.177 \\
(0.112)\end{array}$ & $\begin{array}{l}-0.016 \\
(0.107)\end{array}$ & $\begin{array}{l}-0.045 \\
(0.091)\end{array}$ & $\begin{array}{c}-0.254^{* * *} \\
(0.098)\end{array}$ \\
\hline corruption & $\begin{array}{l}-1.910 \\
(1.505)\end{array}$ & $\begin{array}{l}-1.914 \\
(1.312)\end{array}$ & $\begin{array}{c}-3.349^{* *} \\
(1.371)\end{array}$ & $\begin{array}{c}-4.120^{* * *} \\
(1.368)\end{array}$ & $\begin{array}{c}0.966 \\
(1.295)\end{array}$ & $\begin{array}{c}0.154 \\
(1.129)\end{array}$ & $\begin{array}{c}1.385 \\
(1.261)\end{array}$ \\
\hline rural & $\begin{array}{c}0.222^{* * *} \\
(0.024)\end{array}$ & $\begin{array}{c}0.222^{* * *} \\
(0.024)\end{array}$ & $\begin{array}{c}0.334^{* * *} \\
(0.027)\end{array}$ & $\begin{array}{c}0.311^{* * *} \\
(0.028)\end{array}$ & $\begin{array}{c}-0.168^{* * *} \\
(0.025)\end{array}$ & $\begin{array}{c}-0.160^{* * *} \\
(0.023)\end{array}$ & $\begin{array}{l}-0.027 \\
(0.024)\end{array}$ \\
\hline age & $\begin{array}{c}0.009^{* * *} \\
(0.001)\end{array}$ & $\begin{array}{c}0.009^{* * *} \\
(0.001)\end{array}$ & $\begin{array}{c}0.004^{* * *} \\
(0.001)\end{array}$ & $\begin{array}{c}0.006^{* * *} \\
(0.001)\end{array}$ & $\begin{array}{c}-0.002^{* *} \\
(0.001)\end{array}$ & $\begin{array}{l}-0.001 \\
(0.001)\end{array}$ & $\begin{array}{c}0.006^{* * *} \\
(0.001)\end{array}$ \\
\hline education & $\begin{array}{c}-0.073^{* * *} \\
(0.006)\end{array}$ & $\begin{array}{c}-0.073^{* * *} \\
(0.006)\end{array}$ & $\begin{array}{c}-0.100^{* * *} \\
(0.007)\end{array}$ & $\begin{array}{c}-0.103^{* * *} \\
(0.007)\end{array}$ & $\begin{array}{c}0.016^{* * *} \\
(0.006)\end{array}$ & $\begin{array}{c}0.026^{* * *} \\
(0.006)\end{array}$ & $\begin{array}{c}0.165^{* * *} \\
(0.006)\end{array}$ \\
\hline female & $\begin{array}{l}-0.012 \\
(0.022)\end{array}$ & $\begin{array}{l}-0.012 \\
(0.022)\end{array}$ & $\begin{array}{c}-0.0001 \\
(0.024)\end{array}$ & $\begin{array}{c}0.023 \\
(0.025)\end{array}$ & $\begin{array}{c}-0.081^{* * *} \\
(0.023)\end{array}$ & $\begin{array}{c}-0.067^{* * *} \\
(0.021)\end{array}$ & $\begin{array}{c}-0.243^{* * *} \\
(0.022)\end{array}$ \\
\hline discuss pol & $\begin{array}{c}0.051^{* * *} \\
(0.016)\end{array}$ & $\begin{array}{c}0.051^{* * *} \\
(0.016)\end{array}$ & $\begin{array}{l}-0.014 \\
(0.017)\end{array}$ & $\begin{array}{c}0.109^{* * *} \\
(0.018)\end{array}$ & $\begin{array}{c}0.056^{* * *} \\
(0.016)\end{array}$ & $\begin{array}{c}0.065^{* * *} \\
(0.015)\end{array}$ & $\begin{array}{c}0.287^{* * *} \\
(0.016)\end{array}$ \\
\hline $\begin{array}{l}\text { sponsor* } \\
\text { democracy }\end{array}$ & & $\begin{array}{l}-0.418 \\
(0.313)\end{array}$ & $\begin{array}{l}-0.193 \\
(0.300)\end{array}$ & $\begin{array}{c}-0.753^{*} \\
(0.398)\end{array}$ & $\begin{array}{l}0.731^{* *} \\
(0.313)\end{array}$ & $\begin{array}{c}0.203 \\
(0.293)\end{array}$ & $\begin{array}{c}0.208 \\
(0.239)\end{array}$ \\
\hline Constant & $\begin{array}{c}1.672 \\
(1.277)\end{array}$ & $\begin{array}{l}1.549 \\
(1.107)\end{array}$ & $\begin{array}{c}0.888 \\
(1.083)\end{array}$ & $\begin{array}{l}1.409 \\
(1.060)\end{array}$ & $\begin{array}{l}-0.495 \\
(1.049)\end{array}$ & $\begin{array}{c}0.343 \\
(0.903)\end{array}$ & $\begin{array}{c}0.439 \\
(1.002)\end{array}$ \\
\hline $\begin{array}{l}\text { Individuals } \\
\text { Countries } \\
\text { Log Likel. }\end{array}$ & $\begin{array}{c}44,442 \\
36 \\
-25,977 \\
\end{array}$ & $\begin{array}{c}44,442 \\
36 \\
-25,976 \\
\end{array}$ & $\begin{array}{c}44,646 \\
36 \\
-22,759 \\
\end{array}$ & $\begin{array}{c}41,212 \\
33 \\
-20,860 \\
\end{array}$ & $\begin{array}{c}39,769 \\
35 \\
-24,197 \\
\end{array}$ & $\begin{array}{c}41,765 \\
36 \\
-27,158 \\
\end{array}$ & $\begin{array}{c}45,236 \\
36 \\
-25,991 \\
\end{array}$ \\
\hline
\end{tabular}

Note: Robust standard errors in parentheses. ${ }^{*} \mathrm{p}<0.1 ;{ }^{* *} \mathrm{p}<0.05 ;{ }^{* * *} \mathrm{p}<0.01$ 
Table 4: GLMM Regression Results Round 5 (Physical Integrity)

\begin{tabular}{|c|c|c|c|c|c|c|c|}
\hline & \multicolumn{7}{|c|}{ Dependent variable: } \\
\hline & \multicolumn{2}{|c|}{ trust pres } & \multirow{2}{*}{$\begin{array}{c}\text { trust police } \\
\text { (3) }\end{array}$} & \multirow{2}{*}{$\begin{array}{c}\text { trust ruling } \\
\text { (4) }\end{array}$} & \multirow{2}{*}{$\begin{array}{c}\text { dem pref } \\
(5)\end{array}$} & \multirow{2}{*}{$\begin{array}{c}\text { corr pres } \\
(6)\end{array}$} & \multirow{2}{*}{$\begin{array}{c}\text { trust neighb } \\
\text { (7) }\end{array}$} \\
\hline & (1) & (2) & & & & & \\
\hline sponsor & $\begin{array}{c}0.324^{* * *} \\
(0.057)\end{array}$ & $\begin{array}{c}0.684^{* * *} \\
(0.175)\end{array}$ & $\begin{array}{c}0.514^{* * *} \\
(0.187)\end{array}$ & $\begin{array}{c}0.532^{* * *} \\
(0.204)\end{array}$ & $\begin{array}{c}-0.436^{* * *} \\
(0.151)\end{array}$ & $\begin{array}{c}-0.317^{* *} \\
(0.148)\end{array}$ & $\begin{array}{c}0.070 \\
(0.118)\end{array}$ \\
\hline physical int. & $\begin{array}{l}0.868^{*} \\
(0.505)\end{array}$ & $\begin{array}{c}0.867^{*} \\
(0.498)\end{array}$ & $\begin{array}{c}1.459^{* * *} \\
(0.465)\end{array}$ & $\begin{array}{c}1.605^{* * *} \\
(0.433)\end{array}$ & $\begin{array}{l}0.944^{*} \\
(0.483)\end{array}$ & $\begin{array}{c}-0.835^{*} \\
(0.493)\end{array}$ & $\begin{array}{c}0.017 \\
(0.627)\end{array}$ \\
\hline gdp pc & $\begin{array}{l}-0.190 \\
(0.120)\end{array}$ & $\begin{array}{l}-0.194 \\
(0.121)\end{array}$ & $\begin{array}{c}-0.236^{* *} \\
(0.116)\end{array}$ & $\begin{array}{c}-0.369^{* * *} \\
(0.099)\end{array}$ & $\begin{array}{l}-0.090 \\
(0.093)\end{array}$ & $\begin{array}{l}-0.182 \\
(0.118)\end{array}$ & $\begin{array}{c}-0.251^{*} \\
(0.148)\end{array}$ \\
\hline corruption & $\begin{array}{c}-3.917^{* * *} \\
(1.474)\end{array}$ & $\begin{array}{c}-3.972^{* *} \\
(1.571)\end{array}$ & $\begin{array}{c}-4.790^{* * *} \\
(1.369)\end{array}$ & $\begin{array}{c}-6.112^{* * *} \\
(1.301)\end{array}$ & $\begin{array}{l}2.494^{* *} \\
(1.109)\end{array}$ & $\begin{array}{l}-0.332 \\
(1.395)\end{array}$ & $\begin{array}{c}0.561 \\
(1.894)\end{array}$ \\
\hline rural & $\begin{array}{c}0.242^{* * *} \\
(0.025)\end{array}$ & $\begin{array}{c}0.242^{* * *} \\
(0.025)\end{array}$ & $\begin{array}{c}0.271^{* * *} \\
(0.028)\end{array}$ & $\begin{array}{c}0.285^{* * *} \\
(0.029)\end{array}$ & $\begin{array}{c}0.004 \\
(0.026)\end{array}$ & $\begin{array}{c}-0.119^{* * *} \\
(0.027)\end{array}$ & $\begin{array}{c}0.319^{* * *} \\
(0.024)\end{array}$ \\
\hline age & $\begin{array}{c}0.007^{* * *} \\
(0.001)\end{array}$ & $\begin{array}{c}0.007^{* * *} \\
(0.001)\end{array}$ & $\begin{array}{c}0.004^{* * *} \\
(0.001)\end{array}$ & $\begin{array}{c}0.006^{* * *} \\
(0.001)\end{array}$ & $\begin{array}{c}0.005^{* * *} \\
(0.001)\end{array}$ & $\begin{array}{c}-0.002^{* *} \\
(0.001)\end{array}$ & $\begin{array}{c}0.008^{* * *} \\
(0.001)\end{array}$ \\
\hline education & $\begin{array}{c}-0.103^{* * *} \\
(0.006)\end{array}$ & $\begin{array}{c}-0.103^{* * *} \\
(0.006)\end{array}$ & $\begin{array}{c}-0.113^{* * *} \\
(0.007)\end{array}$ & $\begin{array}{c}-0.116^{* * *} \\
(0.007)\end{array}$ & $\begin{array}{c}0.093^{* * *} \\
(0.007)\end{array}$ & $\begin{array}{c}0.032^{* * *} \\
(0.007)\end{array}$ & $\begin{array}{c}-0.043^{* * *} \\
(0.006)\end{array}$ \\
\hline female & $\begin{array}{c}-0.090^{* * *} \\
(0.022)\end{array}$ & $\begin{array}{c}-0.090^{* * *} \\
(0.022)\end{array}$ & $\begin{array}{c}-0.082^{* * *} \\
(0.024)\end{array}$ & $\begin{array}{c}-0.061^{* *} \\
(0.025)\end{array}$ & $\begin{array}{c}-0.217^{* * *} \\
(0.023)\end{array}$ & $\begin{array}{l}-0.039 \\
(0.025)\end{array}$ & $\begin{array}{c}-0.119^{* * *} \\
(0.022)\end{array}$ \\
\hline discuss pol & $\begin{array}{c}0.046^{* * *} \\
(0.016)\end{array}$ & $\begin{array}{c}0.046^{* * *} \\
(0.016)\end{array}$ & $\begin{array}{c}-0.031^{*} \\
(0.017)\end{array}$ & $\begin{array}{c}0.108^{* * *} \\
(0.018)\end{array}$ & $\begin{array}{c}0.251^{* * *} \\
(0.017)\end{array}$ & $\begin{array}{c}0.096^{* * *} \\
(0.018)\end{array}$ & $\begin{array}{l}-0.004 \\
(0.016)\end{array}$ \\
\hline $\begin{array}{l}\text { sponsor* } \\
\text { physical int. }\end{array}$ & & $\begin{array}{c}-0.546^{* *} \\
(0.253)\end{array}$ & $\begin{array}{l}-0.436 \\
(0.273)\end{array}$ & $\begin{array}{l}-0.348 \\
(0.292)\end{array}$ & $\begin{array}{c}0.316 \\
(0.224)\end{array}$ & $\begin{array}{c}0.257 \\
(0.220)\end{array}$ & $\begin{array}{l}-0.017 \\
(0.173)\end{array}$ \\
\hline Constant & $\begin{array}{l}1.985 \\
(1.307)\end{array}$ & $\begin{array}{l}2.046 \\
(1.306)\end{array}$ & $\begin{array}{c}2.001 \\
(1.267)\end{array}$ & $\begin{array}{c}3.198^{* * *} \\
(1.037)\end{array}$ & $\begin{array}{l}-0.658 \\
(0.971)\end{array}$ & $\begin{array}{l}1.099 \\
(1.227)\end{array}$ & $\begin{array}{c}1.759 \\
(1.639)\end{array}$ \\
\hline $\begin{array}{l}\text { Observations } \\
\text { Countries } \\
\text { Log Likeli. }\end{array}$ & $\begin{array}{c}41,046 \\
33 \\
-24,678 \\
\end{array}$ & $\begin{array}{c}41,046 \\
33 \\
-24,676 \\
\end{array}$ & $\begin{array}{c}42,574 \\
34 \\
-21,784 \\
\end{array}$ & $\begin{array}{c}40,228 \\
33 \\
-20,544 \\
\end{array}$ & $\begin{array}{c}43,301 \\
34 \\
-23,444 \\
\end{array}$ & $\begin{array}{c}36,376 \\
33 \\
-21,008 \\
\end{array}$ & $\begin{array}{c}43,158 \\
34 \\
-25,970 \\
\end{array}$ \\
\hline
\end{tabular}

Note: Robust standard errors in parentheses. ${ }^{*} \mathrm{p}<0.1 ;{ }^{* *} \mathrm{p}<0.05 ;{ }^{* * *} \mathrm{p}<0.01$ 
In order to make the interaction effects more interpretable figure 1 to 6 visualize the average marginal effects of suspecting the survey to be sponsored by the government over the full range of the Electoral Democracy Index for model 2 to 7 from table 3 and model 7 from table 2. These marginal effect plots include all control variables from the respective models. Figure 1 shows how the effect of suspecting the survey sponsor on trust in the president or prime minister decreases with an increase in the level of Electoral Democracy, all else equal. At low levels of democracy the effect is substantive and significant, whereas at higher levels of democracy the effect diminishes and is no longer significant in countries with a level of democracy above .8. Figure 2 shows a even more pronounced pattern for "Trust in Ruling Party". There is a clear autocratic trust bias with regards to stated trust in the rulers.

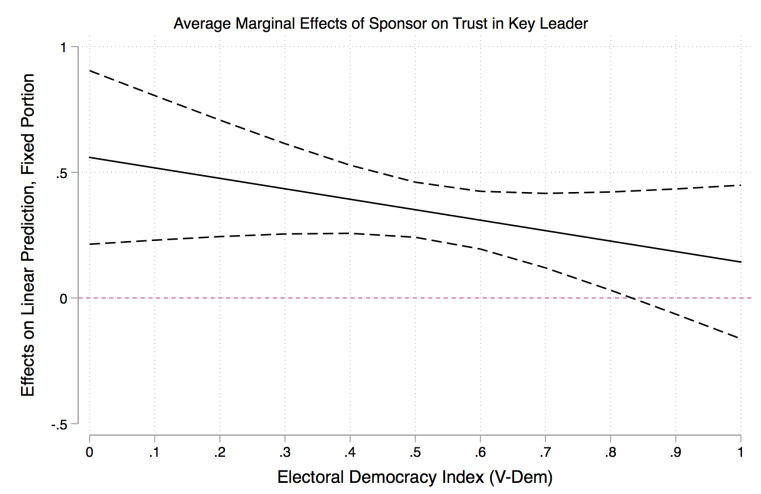

Figure 1: Marginal effect on trust in key leader

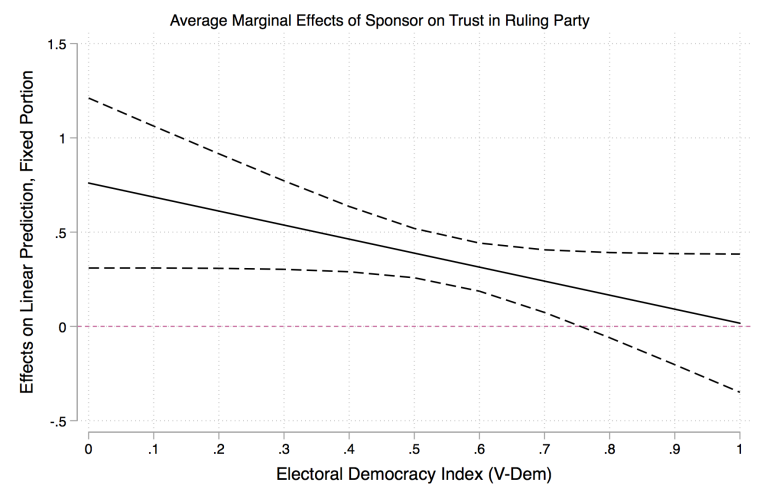

Figure 2: Marginal effect trust in ruling party

In the model specification where the less (but still) sensitive item "Trust the Police" is employed as the dependent variable we again note a tendency to inflate the reported level of trust. As illustrated in figure 3 this bias is substantively smaller, yet significant and systematically related to the level of democracy. As expected there is no effect of with regards to the apolitical and non-sensitive item "Trust your neighbors" (see figure 4). The effect is unsubstantial and insignificant across the full range of the Electoral Democracy Index.

Figure 5 and figure 6 again show that the autocratic bias is more pronounced in respondents' evaluation of the rulers than of civil servants. There is a strong and significant effect on stated perceptions about corruption in the president's or prime minister's office, while for stated perceptions about corruption in the taxation agency less substantial and insignificant at most levels of electoral democracy.

Figure 7 shows how respondents preference for democracy is systematically biased across the level of democracy. Studies concerned with public demand for democracy (cf. (Mattes and Bratton, 2007)), likely underestimate the true demand due to this downward bias in more more autocratic countries.

Breaking down the results by country Figure 8 displays estimated effects of suspecting 


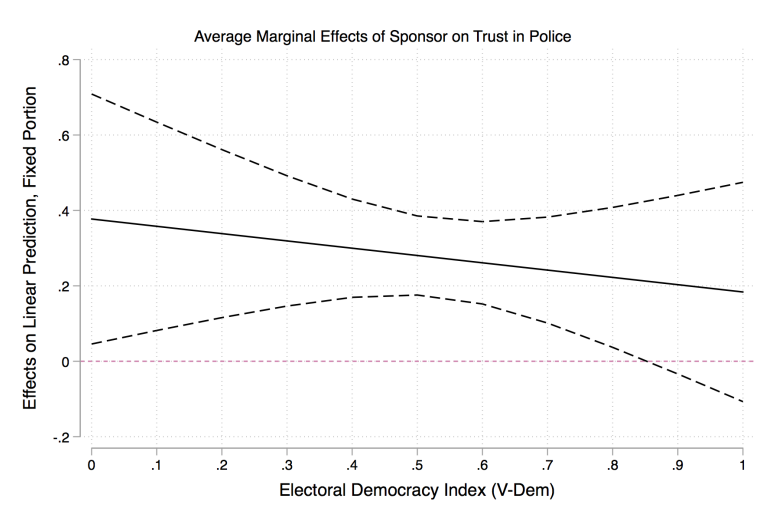

Figure 3: Marginal effect on trust in police

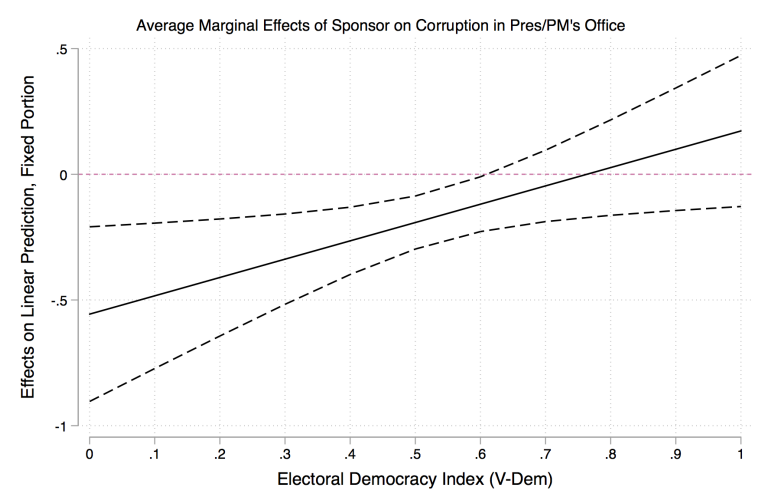

Figure 5: Marginal effect on corruption pres/PM

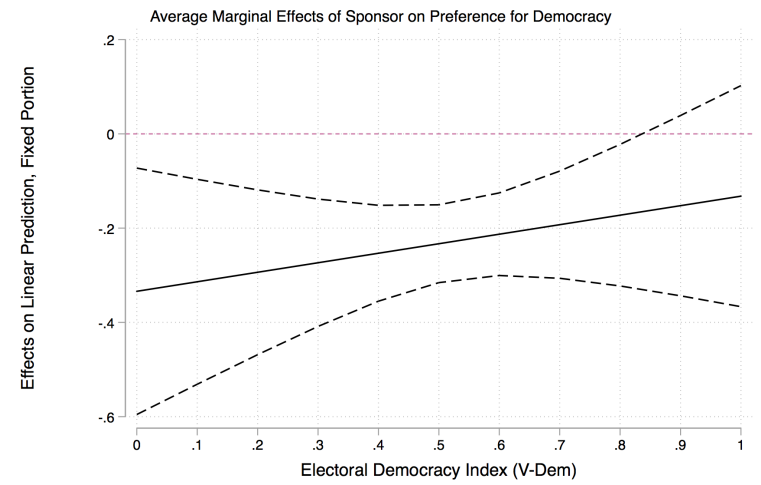

Figure 7: Marginal effect on preference for democracy

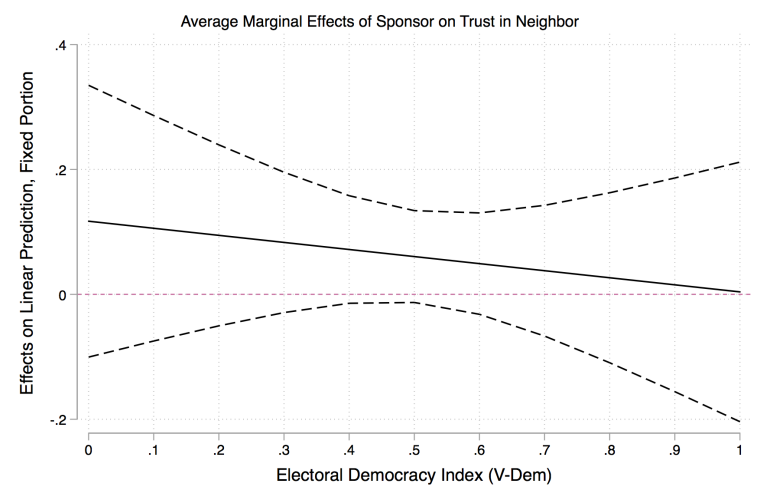

Figure 4: Marginal effect on trust in neighbors

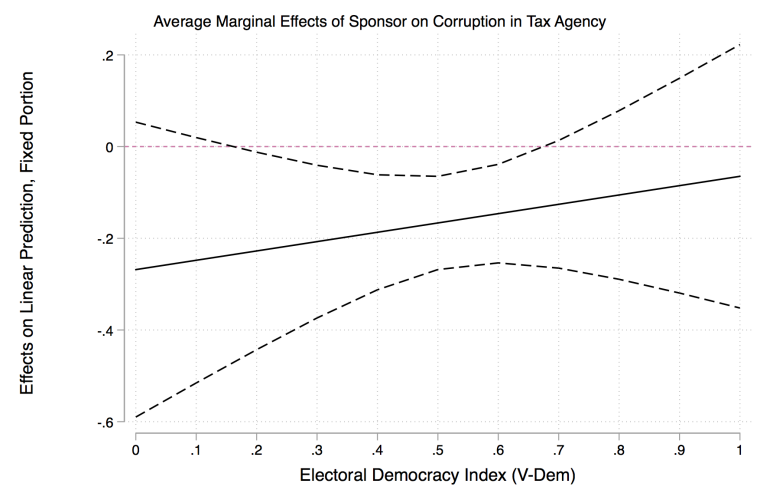

Figure 6: Marginal effect on corruption tax agency

the government as sponsor of the survey for each country in the 6th round of the Afrobarometer. The list of countries are sorted in order of their Electoral Democracy Score, from low 
to high levels of democracy. The effects are expressed as the odds ratio of a respondent that believes the government sponsor the survey to indicate "A lot" of trust in the country's key leadership figure, with 95 percent confidence intervals. Estimates for which the confidence intervals do not overlap with 1 (dotted line) indicate a statistically significant difference between the two respondent groups' propensity to report a lot of trust, after controlling for the above mentioned set of individual level predictors. In substantive terms the estimated effect in, for example Guinea, is to be interpreted as follows: suspecting respondents are 2.75 times more likely to report a lot of trust in the president compared to non-suspecting respondents. By-and-large this plot lends credence to the autocratic trust bias hypothesis. In countries with high levels of democracy the effect is small or insignificant, and in more autocratic countries the effect is more often larger and significant. Figure 10 in Appendix $A$ shows the effect for each of the 124 country years in the full sample, produce the same pattern. It is noteworthy that a number of arguably very repressive regimes do not enjoy the autocratic trust bias. Sudan stands out among the autocratic countries as respondents who believe the government to sponsor the survey, in fact are less inclined to report high trust in president al-Bashir. Furthermore, the variation among countries at comparable, and comparatively high levels of Electoral Democracy is intriguing and calls for investigation into whether this might be driven by an interaction between suspecting government as sponsor and patronage and vote buying on the country level.

Figure 9 highlights two cases where we observe large changes over time in the propensity to indicate "A lot" of trust in the country's president when the respondent suspects government sponsorship. In Kenya there was no significant effect of believing that the government had sent the enumerator on respondents propensity to indicate high trust in the country's president in 2003 and 2005. In the aftermath of the 200\%-08 Kenyan crisis, which saw some 1300 people dead and 600000 people displaced following politically motivated (Kagwanja and Southall, 2009; Rutten and Owuor, 2009), and allegedly state sponsored violence (HRW, 2008), respondents where statistically significantly and substantively (1.86 times) more likely to indicate that they trusted president Kibaki "A lot" when they believed that the survey was not independent ${ }^{4}$. Breaking citizens' trust seams to be associated with higher levels of reported trust from the very same. In the subsequent rounds of the Afrobarometer there is still an significant effect of suspecting the survey sponsor, albeit weaker. Madagascar is the one country in the sample with the largest decrease in Electoral Democracy Score between 2005 and 2012, from 0.53 to 0.23. Following the 2009 Malagasy political crisis which culminated in the unconstitutional transfer of executive power, political repression increased (Ploch and Cook, 2012). In line with my expectations respondents' propensity to self-censor has increased over this time period and in 2012 respondents believing that the government sponsored the survey was more than twice as likely to report that they had "A lot" of trust in president Rajoelina. In 2013 and 2014 Madagascar's electoral democracy score improved to more moderate a .48 and in the most recent round of the Afrobarometer we no longer observe a significant effect between these two groups of respondents.

\footnotetext{
${ }^{4}$ Expressed in predicted probabilities, the between group difference is 12 percentage points, holding the control variables at their means
} 
Figure 8: Estimated effects of suspecting government sponsorship on trust in key leader across African countries in decending order of Electroal Democracy Score

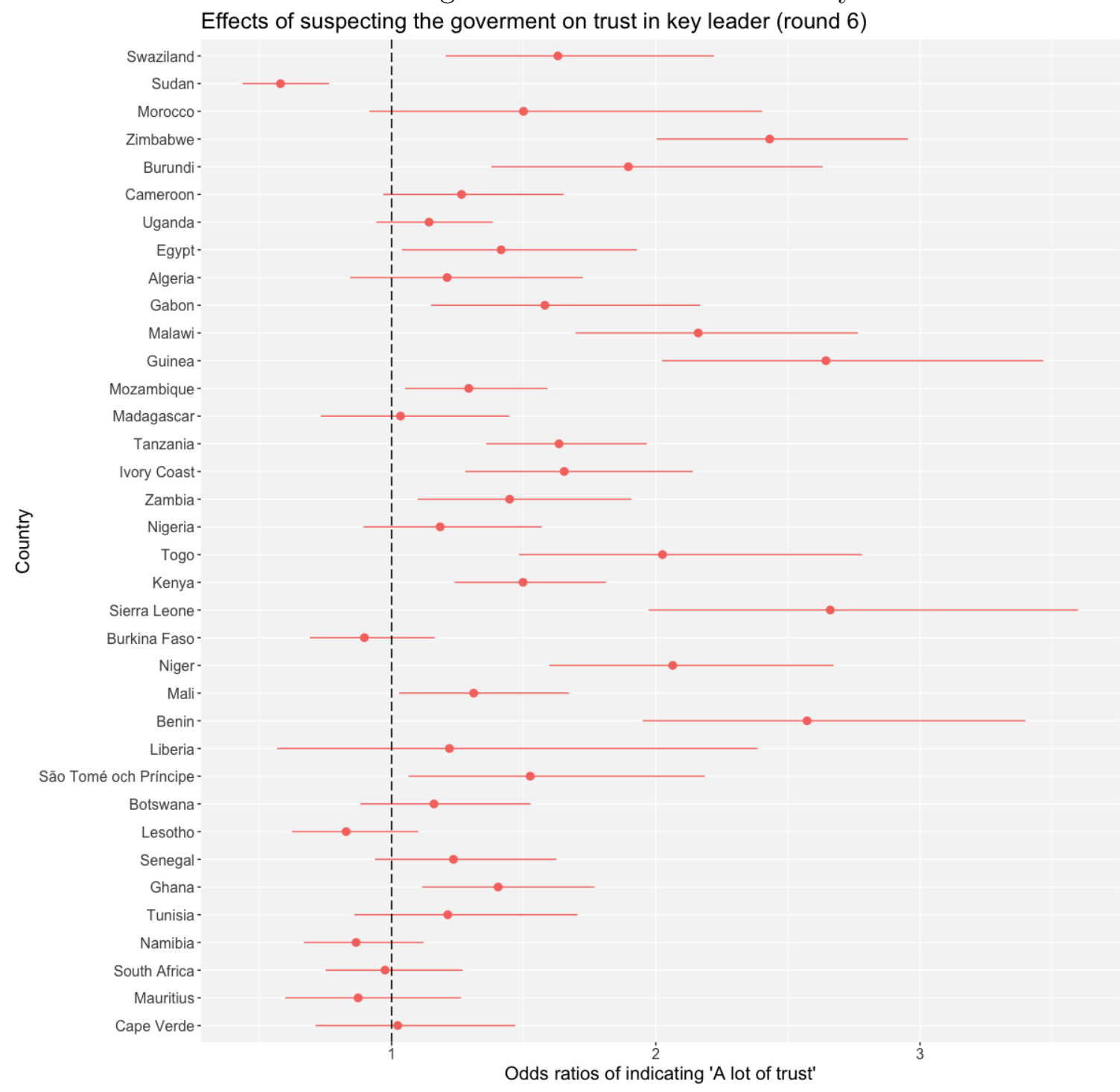


Figure 9: Estimated effects of suspecting government sponsorship on trust in key leader in Kenya and Madagascar
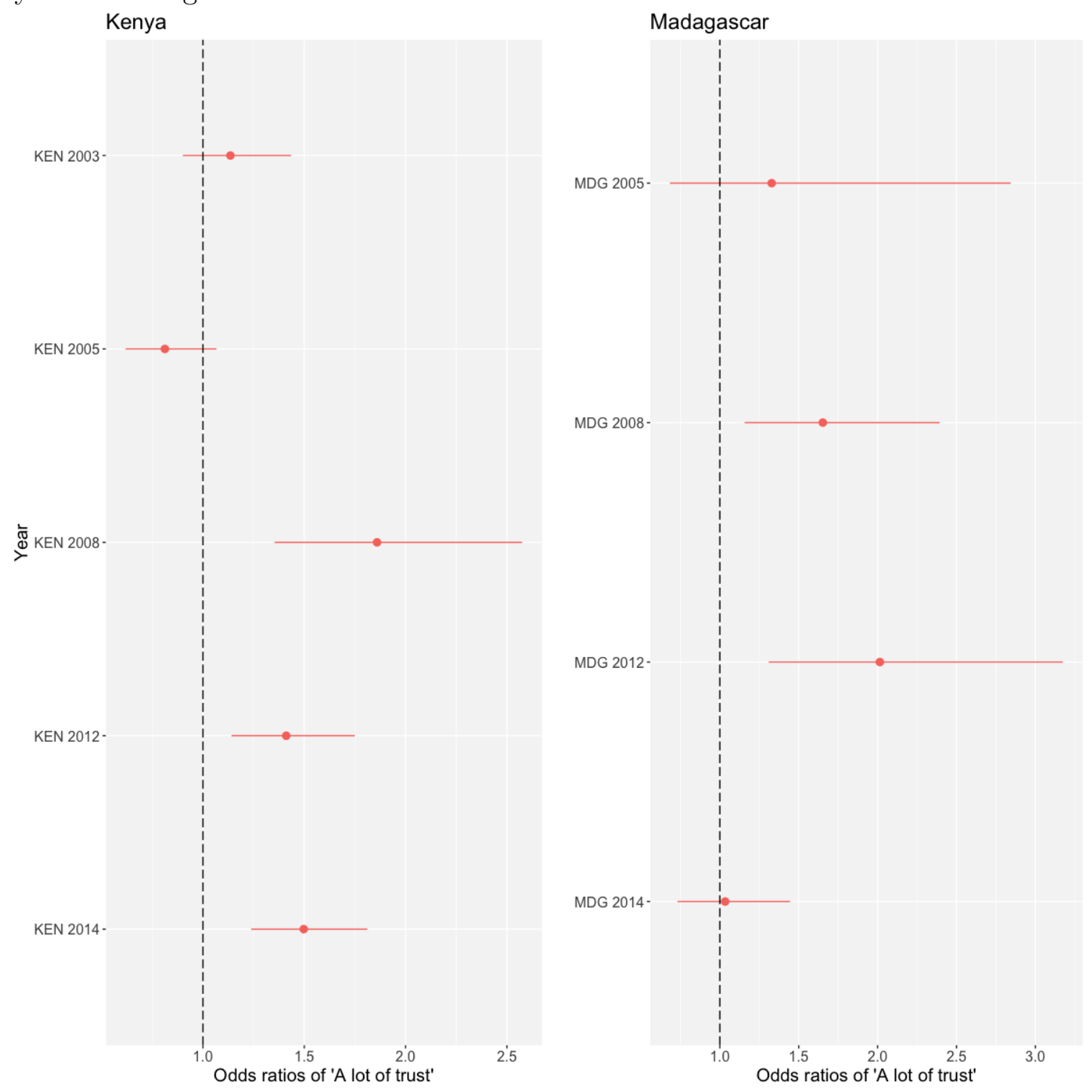


\section{Discussion}

This paper shows that the effects of respondents' belief of who administrates the survey substantially influence answers on politically sensitive questions in more autocratic countries, and less so in more democratic countries. I want to point out that, while the estimated effects are already large to cause concern for the comparability of the particular survey items, I am if anything underestimating the true effects, because even respondents who believe the enumerator to be from a independent research organization may adopt a adopt a better-safethan-sorry-approach out of fear that the authorities can use the survey to trace unsanctioned opinions to an individual, a neighborhood or a village.

To summarize, sensitive questions evaluating the ruler/s suffer from a larger bias than do questions evaluating those exercising public power. This is evident by the the larger effect for trust in the key leadership figure or ruling party compared to trust in the police, as well as by the difference in the effect on stated perceptions of corruption in the president/prime minister's office and in the tax authorities. The innocuous question about trust in your neighbors provides perfect a placebo test for the Autocratic Trust Bias hypothesis as one would expect no difference between the two groups of respondents' answers, no matter the level of political repression. Indeed there is none.

The usefulness of an survey item probing for the respondents sense of anonymity should be evident, and ideally added to surveys with the ambition to be comparable across countries where the doubt of anonymity are likely to produce different response behavior. Is the solution then simply to drop the "fearful" respondents from any comparative analysis of sensitive items? For a number of reasons relating to the representativeness of the sample that would be a bad idea. Having estimated the bias for a set of sensitive items, one avenue forward would be to construct reliability weights to enable the researcher to account for the biases in the analysis. 


\section{References}

Adida, Claire L et al. (2016). "Whos asking? Interviewer coethnicity effects in African survey data". In: Comparative Political Studies 49.12, pp. 1630-1660.

Afrobarometer, Data (2016). "All countries, Rounds 2, 3, 4, 5, 6, availible at". In: http://www. afrobarometer.org.

Aguinis, Herman, Ryan K Gottfredson, and Steven Andrew Culpepper (2013). "Best-practice recommendations for estimating cross-level interaction effects using multilevel modeling". In: Journal of Management 39.6, pp. 1490-1528.

AsianBarometer (2008). "Asian Barometer Survey Data Release: 2001-2003, 2005-2008". In: URL: http://www. asianbarometer. org.

Booth, John A and Mitchell A Seligson (2009). The legitimacy puzzle in Latin America: Political support and democracy in eight nations. Cambridge University Press.

Boräng, Frida, Marina Nistotskaya, and Georgios Xezonakis (2017). "The quality of government determinants of support for democracy". In: Journal of Public Affairs 17.1-2.

Brambor, Thomas, William Roberts Clark, and Matt Golder (2006). "Understanding interaction models: Improving empirical analyses". In: Political analysis, pp. 63-82.

Bratton, Michael, Ravi Bhavnani, and Tse-Hsin Chen (2012). "Voting intentions in Africa: ethnic, economic or partisan?" In: Commonwealth 6 Comparative Politics 50.1, pp. 2752.

Bratton, Michael and Eldred Masunungure (2012). "Voting intentions in Zimbabwe: A margin of terror". In: Afrobarometer Briefing Paper 103.

Carlson, Elizabeth (2014). Social desirability bias and reported vote preferences in African surveys. Tech. rep. Afrobarometer Working Papers. Working Paper.

Chung, Janne and Gary S Monroe (2003). "Exploring social desirability bias". In: Journal of Business Ethics 44.4, pp. 291-302.

Coppedge, Michael et al. (2017a). "V-Dem Codebook V7". In: Varieties of Democracy (VDem) Project.

Coppedge, Michael et al. (2017b). "V-Dem [Country-Year/Country-Date] Dataset v7". In: Varieties of Democracy (V-Dem) Project.

Coppedge, Michael et al. (2017c). "V-Dem Methodology v7". In: Varieties of Democracy (V-Dem) Project.

Corstange, Daniel (2014). "Foreign-Sponsorship Effects in Developing-World Surveys Evidence From a Field Experiment in Lebanon". In: Public Opinion Quarterly, nfu024.

Frye, Timothy et al. (2017). "Is Putins popularity real?" In: Post-Soviet Affairs 33.1, pp. 115. 
Garcia-Ponce, Omar and Benjamin Pasquale (2015). "How Political Repression Shapes Attitudes Toward the State: Evidence from Zimbabwe". In: Working Paper.

Gilley, Bruce (2006a). "The determinants of state legitimacy: Results for 72 countries". In: International political science review 27.1, pp. 47-71.

- (2006b). "The meaning and measure of state legitimacy: Results for 72 countries". In: European Journal of Political Research 45.3, pp. 499-525.

Guriev, Sergei M and Daniel Treisman (2016). "What makes governments popular?" In: APSA Conference Paper.

Holbrook, Allyson L and Jon A Krosnick (2010). "Social desirability bias in voter turnout reports Tests using the item count technique". In: Public Opinion Quarterly 74.1, pp. 3767.

HRW, Organization (2008). "Ballots to Bullets: Organized Political Violence and Kenya's Crisis of Governance." In: Human Rights Watch.

Jiang, Junyan and Dali L Yang (2016). "Lying or Believing? Measuring Preference Falsification From a Political Purge in China". In: Comparative Political Studies 49.5, pp. 600634.

Kagwanja, Peter and Roger Southall (2009). "Kenya's uncertain democracy: the electoral crisis of 2008". In: Journal of Contemporary African Studies 27.3, pp. 257-461.

Kalinin, Kirill (2014). "A Study of Social Desirability Bias in the Russian Presidential Elections, 2012". In: APSA 2014 Annual Meeting Paper.

Krumpal, Ivar (2013). "Determinants of social desirability bias in sensitive surveys: a literature review". In: Quality \&3 Quantity 47.4, pp. 2025-2047.

Kuklinski, James H, Michael D Cobb, and Martin Gilens (1997). "Racial attitudes and the New South". In: The Journal of Politics 59.02, pp. 323-349.

Kuran, Timur (1997). Private truths, public lies: The social consequences of preference falsification. Harvard University Press.

Linz, Juan José (2000). Totalitarian and authoritarian regimes. Lynne Rienner Publishers.

Marquardt, Kyle L and Daniel Pemstein (2017). "IRT Models for Expert-Coded Panel Data". In: University of Gothenburg, Varieties of Democracy Institute: Working Paper 41.

Mattes, Robert and Michael Bratton (2007). "Learning about democracy in Africa: Awareness, performance, and experience". In: American Journal of Political Science 51.1, pp. $192-217$.

Mattes, Robert and Mulu Teka (2016). "Ethiopians views of democratic government: Fear, ignorance, or unique understanding of democracy?" In: Afrobarometer Working Paper 164. 
McMann, Kelly M et al. (2016). "Strategies of Validation: Assessing the Varieties of Democracy Corruption Data". In: University of Gothenburg, Varieties of Democracy Institute: Working Paper 23.

Moehler, Devra C (2009). "Critical citizens and submissive subjects: Election losers and winners in Africa". In: British Journal of Political Science 39.02, pp. 345-366.

Moehler, Devra C and Staffan I Lindberg (2009). "Narrowing the legitimacy gap: Turnovers as a cause of democratic consolidation". In: The Journal of Politics 71.04, pp. 1448-1466.

Pemstein, Daniel et al. (2017). "The V-Dem Measurement Model: Latent Variable Analysis for Cross-National and Cross-Temporal Expert-Coded Data". In: University of Gothenburg, Varieties of Democracy Institute: Working Paper 21.

Ploch, Lauren and Nicolas Cook (2012). Madagascar's Political Crisis.

Rothstein, Bo (2011). The quality of government: Corruption, social trust, and inequality in international perspective. University of Chicago Press.

Rutten, Marcel and Sam Owuor (2009). "Weapons of mass destruction: Land, ethnicity and the 2007 elections in Kenya". In: Journal of Contemporary African Studies 27.3, pp. 305324.

Schedler, Andreas (1999). The self-restraining state: power and accountability in new democracies. Lynne Rienner Publishers.

Teorell, Jan et al. (2016). "Measuring Electoral Democracy with V-Dem Data: Introducing a New Polyarchy Index". In: University of Gothenburg, Varieties of Democracy Institute: Working Paper 25.

Tourangeau, Roger and Ting Yan (2007). "Sensitive questions in surveys". In: Psychological bulletin 133.5, p. 859. 


\section{A Appendix A}

Figure 10 shows the effect of suspecting the survey sponsor on trust in the key leadership figure for all 124 country years. Sorted from most autocratic on top down to most democratic. Again, in general in more democratic settings there is either a non significant small effect and in more autocratic settings the effect is more often significant and oftentimes substantial. Several arguably very repressive regime does not enjoy the autocratic trust bias. Notably in 2012, four of these Morocco, Tunisia, Algeria and Egypt are not only geographically and culturally distinct from the larger sample but, were also affected by the Arab Spring. It is possible that the rebellious moods increased respondents propensity to speak truth to power.

Table 6 show that results also hold when when the models are run using full data set, with more than 140 thousand respondents across 124 country years. Note that when changing the the level two unit of analysis from country to country years, the level two units are no longer independent and some countries are only represented by 1 country year while others are represented by 5 country years.

In Table 7 and table 8 the main independent variable is re-coded so that both respondents that suspect the government to sponsor the survey as well as those that do not know are coded as 1 . Save for that the effect sizes decreases marginally the results are identical to those reported in table 2 and table 3. The smaller effect sizes are to be expected given that not knowing the survey sponsor in all likelihood is a "weaker treatment" than believing that it is the government.

Table 9 reports the results from the round 6 of the Afrobarometer with the main dependent variables re-coded so that trusting "somewhat" or "a lot" is coded as 1, and "Not at all" or "Just a little" are coded as 0 . The effects are substantively smaller yet still significant. This could be indicative of that respondents indeed are more likely to pick the safest possible option (i.e. "a lot") when believing the government is behind the survey - when falsifying your preferences you might as well do it fully. 
Figure 10: Effect of sponsor on trust in key leader round 2-6 Effects of suspecting the goverment on trust in key leader (round 2 to 6 )

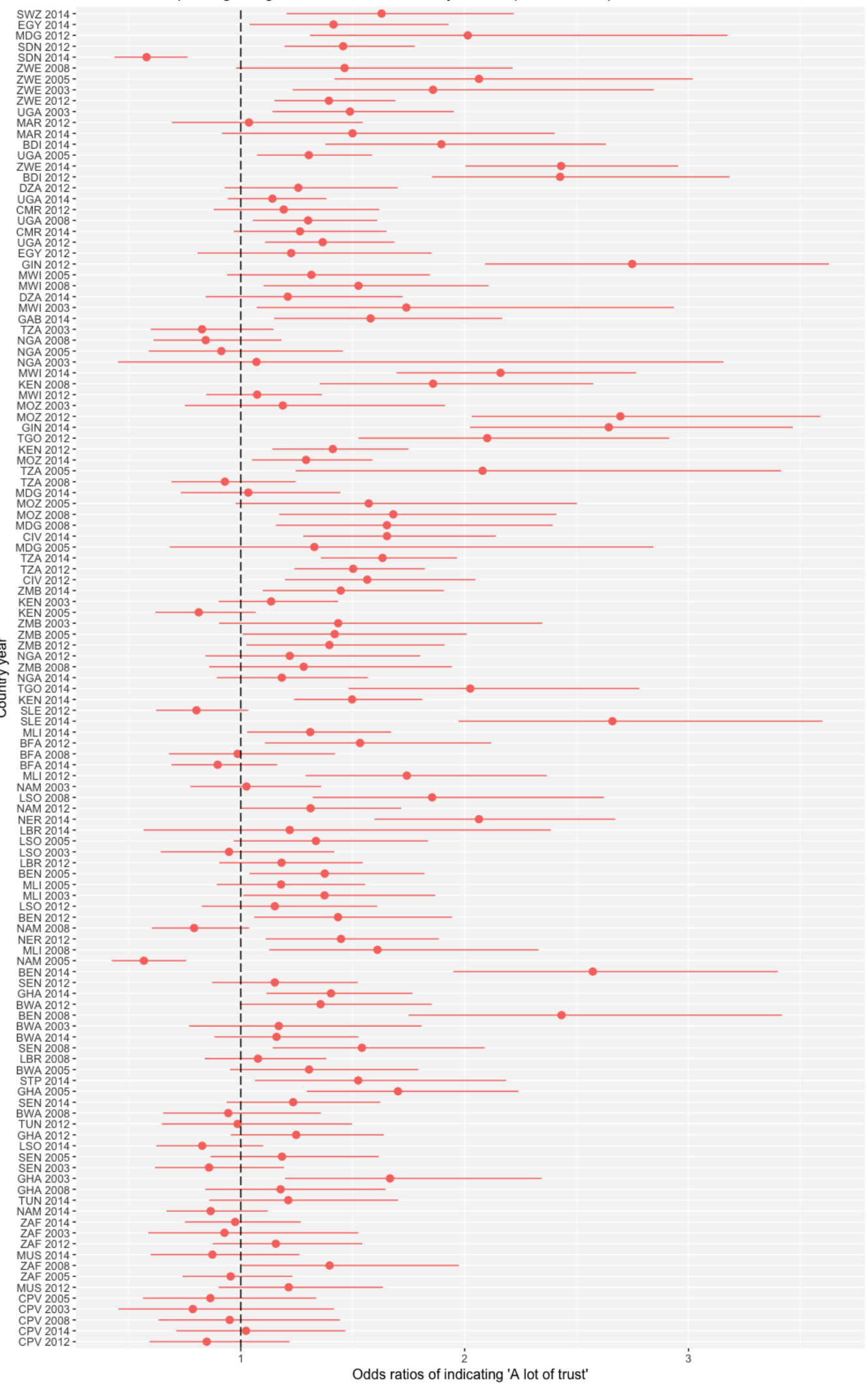


Table 5: GLMM Regression Results Round 6 - including slope and intercept variance

\begin{tabular}{|c|c|c|c|c|c|c|c|}
\hline & \multicolumn{7}{|c|}{ Dependent variable: } \\
\hline & \multicolumn{2}{|c|}{ trust leader } & \multirow{2}{*}{$\begin{array}{c}\text { trust police } \\
\text { (3) }\end{array}$} & \multirow{2}{*}{$\begin{array}{c}\text { trust rparty } \\
\text { (4) }\end{array}$} & \multirow{2}{*}{$\begin{array}{c}\text { corr pres } \\
(5)\end{array}$} & \multirow{2}{*}{$\begin{array}{l}\text { corr tax } \\
(6)\end{array}$} & \multirow{2}{*}{$\begin{array}{c}\text { dem pref } \\
(7)\end{array}$} \\
\hline & $(1)$ & $(2)$ & & & & & \\
\hline sponsor & $\begin{array}{c}0.336^{* * *} \\
(0.056)\end{array}$ & $\begin{array}{c}0.560^{* * *} \\
(0.176)\end{array}$ & $\begin{array}{c}0.377^{* *} \\
(0.169)\end{array}$ & $\begin{array}{c}0.765^{* * *} \\
(0.230)\end{array}$ & $\begin{array}{c}-0.557^{* * *} \\
(0.177)\end{array}$ & $\begin{array}{l}-0.268 \\
(0.164)\end{array}$ & $\begin{array}{c}-0.337^{* *} \\
(0.133)\end{array}$ \\
\hline democracy & $\begin{array}{l}-0.564 \\
(0.615)\end{array}$ & $\begin{array}{l}-0.320 \\
(0.626)\end{array}$ & $\begin{array}{c}0.726 \\
(0.592)\end{array}$ & $\begin{array}{c}0.618 \\
(0.720)\end{array}$ & $\begin{array}{l}-0.770 \\
(0.638)\end{array}$ & $\begin{array}{l}-0.686 \\
(0.501)\end{array}$ & $\begin{array}{c}1.475^{* * *} \\
(0.552)\end{array}$ \\
\hline $\begin{array}{l}\text { sponsor* } \\
\text { democracy }\end{array}$ & & $\begin{array}{l}-0.418 \\
(0.313)\end{array}$ & $\begin{array}{l}-0.193 \\
(0.300)\end{array}$ & $\begin{array}{c}-0.753^{*} \\
(0.398)\end{array}$ & $\begin{array}{l}0.731^{* *} \\
(0.313)\end{array}$ & $\begin{array}{c}0.203 \\
(0.293)\end{array}$ & $\begin{array}{c}0.208 \\
(0.239)\end{array}$ \\
\hline individual cont. & yes & yes & yes & yes & yes & yes & yes \\
\hline country cont. & yes & yes & yes & yes & yes & yes & yes \\
\hline Constant & $\begin{array}{c}1.672 \\
(1.277)\end{array}$ & $\begin{array}{c}1.549 \\
(1.107)\end{array}$ & $\begin{array}{c}0.888 \\
(1.083)\end{array}$ & $\begin{array}{c}1.409 \\
(1.060)\end{array}$ & $\begin{array}{l}-0.495 \\
(1.049)\end{array}$ & $\begin{array}{c}0.343 \\
(0.903)\end{array}$ & $\begin{array}{c}0.439 \\
(1.002)\end{array}$ \\
\hline Random intercept (var) & $\begin{array}{c}1.672 \\
(1.277)\end{array}$ & $\begin{array}{l}1.549 \\
(1.107)\end{array}$ & $\begin{array}{c}0.888 \\
(1.083)\end{array}$ & $\begin{array}{c}1.409 \\
(1.060)\end{array}$ & $\begin{array}{l}-0.495 \\
(1.049)\end{array}$ & $\begin{array}{c}0.343 \\
(0.903)\end{array}$ & $\begin{array}{c}0.439 \\
(1.002)\end{array}$ \\
\hline Random slope (var) & $\begin{array}{c}1.672 \\
(1.277)\end{array}$ & $\begin{array}{c}1.549 \\
(1.107)\end{array}$ & $\begin{array}{c}0.888 \\
(1.083)\end{array}$ & $\begin{array}{c}1.409 \\
(1.060)\end{array}$ & $\begin{array}{l}-0.495 \\
(1.049)\end{array}$ & $\begin{array}{c}0.343 \\
(0.903)\end{array}$ & $\begin{array}{c}0.439 \\
(1.002)\end{array}$ \\
\hline $\begin{array}{l}\text { Observations } \\
\text { Countries } \\
\text { Log Likelihood }\end{array}$ & $\begin{array}{c}44,442 \\
36 \\
-25,977.6\end{array}$ & $\begin{array}{c}44,442 \\
36 \\
-25,976.8\end{array}$ & $\begin{array}{c}44,646 \\
36 \\
-22,759.2\end{array}$ & $\begin{array}{c}41,212 \\
33 \\
-20,860.4\end{array}$ & $\begin{array}{c}39,769 \\
35 \\
-24,197.6\end{array}$ & $\begin{array}{c}41,765 \\
36 \\
-27,158.7\end{array}$ & $\begin{array}{c}45,236 \\
36 \\
-25,991.4\end{array}$ \\
\hline
\end{tabular}

Note: Robust standard errors in parentheses. ${ }^{*} \mathrm{p}<0.1 ;{ }^{* *} \mathrm{p}<0.05 ;{ }^{* * *} \mathrm{p}<0.01$ Individual-level controls include: gender, age, rural, discuss politics. Country-level controls include GDP per capita (logged) and corruption. 
Table 6: GLMM Regression Results Round 2-6

\begin{tabular}{|c|c|c|c|c|c|c|c|}
\hline & \multicolumn{7}{|c|}{ Dependent variable: } \\
\hline & \multicolumn{2}{|c|}{ trust leader } & \multirow{2}{*}{$\begin{array}{c}\text { trust police } \\
(3)\end{array}$} & \multirow{2}{*}{$\begin{array}{c}\text { trust rparty } \\
(4)\end{array}$} & \multirow{2}{*}{$\begin{array}{c}\text { prefer dem } \\
(5)\end{array}$} & \multirow{2}{*}{$\begin{array}{c}\text { corr pres } \\
(6)\end{array}$} & \multirow{2}{*}{$\begin{array}{c}\text { corr tax } \\
(7)\end{array}$} \\
\hline & $(1)$ & $(2)$ & & & & & \\
\hline sponsor & $\begin{array}{c}0.281^{* * *} \\
(0.031)\end{array}$ & $\begin{array}{c}0.664^{* * *} \\
(0.098)\end{array}$ & $\begin{array}{c}0.564^{* * *} \\
(0.113)\end{array}$ & $\begin{array}{c}0.692^{* * *} \\
(0.117)\end{array}$ & $\begin{array}{c}-0.373^{* * *} \\
(0.076)\end{array}$ & $\begin{array}{c}-0.340^{* * *} \\
(0.100)\end{array}$ & $\begin{array}{c}-0.245^{* * *} \\
(0.091)\end{array}$ \\
\hline democracy & $\begin{array}{c}0.642 \\
(0.464)\end{array}$ & $\begin{array}{l}0.885^{* *} \\
(0.442)\end{array}$ & $\begin{array}{c}1.527^{* * *} \\
(0.408)\end{array}$ & $\begin{array}{c}1.656^{* * *} \\
(0.462)\end{array}$ & $\begin{array}{c}1.104^{* * *} \\
(0.299)\end{array}$ & $\begin{array}{c}-1.088^{* * *} \\
(0.406)\end{array}$ & $\begin{array}{c}-1.015^{* * *} \\
(0.344)\end{array}$ \\
\hline $\begin{array}{l}\text { sponsor* } \\
\text { democracy }\end{array}$ & & $\begin{array}{c}-0.696^{* * *} \\
(0.171)\end{array}$ & $\begin{array}{c}-0.628^{* * *} \\
(0.195)\end{array}$ & $\begin{array}{c}-0.696^{* * *} \\
(0.200)\end{array}$ & $\begin{array}{l}0.319^{* *} \\
(0.135)\end{array}$ & $\begin{array}{l}0.414^{* *} \\
(0.176)\end{array}$ & $\begin{array}{c}0.273^{*} \\
(0.161)\end{array}$ \\
\hline individual cont. & yes & yes & yes & yes & yes & yes & yes \\
\hline country cont. & yes & yes & yes & yes & yes & yes & yes \\
\hline Constant & $\begin{array}{c}0.904 \\
(1.042)\end{array}$ & $\begin{array}{c}0.785 \\
(0.775)\end{array}$ & $\begin{array}{l}-0.316 \\
(0.729)\end{array}$ & $\begin{array}{c}1.328^{*} \\
(0.771)\end{array}$ & $\begin{array}{l}-0.757 \\
(0.555)\end{array}$ & $\begin{array}{l}-0.429 \\
(0.725)\end{array}$ & $\begin{array}{c}0.937 \\
(0.745)\end{array}$ \\
\hline $\begin{array}{l}\text { Observations } \\
\text { Country years } \\
\text { Log Likel. } \\
\end{array}$ & $\begin{array}{c}145,358 \\
123 \\
-84,398 \\
\end{array}$ & $\begin{array}{c}145,358 \\
123 \\
-84,390 \\
\end{array}$ & $\begin{array}{c}147,910 \\
124 \\
-72,535 \\
\end{array}$ & $\begin{array}{c}140,986 \\
120 \\
-71,710 \\
\end{array}$ & $\begin{array}{c}150,646 \\
124 \\
-85,772 \\
\end{array}$ & $\begin{array}{c}111,090 \\
106 \\
-65,178 \\
\end{array}$ & $\begin{array}{c}114,434 \\
108 \\
-73,853 \\
\end{array}$ \\
\hline
\end{tabular}

Note: Robust standard errors in parentheses. ${ }^{*} \mathrm{p}<0.1 ;{ }^{* *} \mathrm{p}<0.05 ;{ }^{* * *} \mathrm{p}<0.01$ Individual-level controls include: gender, age, rural, discuss politics. Country-level controls include GDP per capita (logged) and corruption 
Table 7: GLMM Regression Results Round 6 (alternative IV)

\begin{tabular}{|c|c|c|c|c|c|c|c|}
\hline & \multicolumn{7}{|c|}{ Dependent variable: } \\
\hline & \multicolumn{2}{|c|}{ alot_trust } & \multirow{2}{*}{$\begin{array}{c}\text { alot_policetrust } \\
(3)\end{array}$} & \multirow{2}{*}{$\begin{array}{c}\text { alot_rulptrust } \\
(4)\end{array}$} & \multirow{2}{*}{$\begin{array}{c}\text { dem_pref } \\
(5)\end{array}$} & \multirow{2}{*}{$\begin{array}{c}\text { corr_pres } \\
(6)\end{array}$} & \multirow{2}{*}{$\begin{array}{c}\text { corr_tax } \\
(7)\end{array}$} \\
\hline & $(1)$ & $(2)$ & & & & & \\
\hline $\begin{array}{l}\text { sponsor } \\
(\text { gov+dont know) }\end{array}$ & $\begin{array}{c}0.292^{* * *} \\
(0.057)\end{array}$ & $\begin{array}{c}0.527^{* * *} \\
(0.181)\end{array}$ & $\begin{array}{l}0.362^{* *} \\
(0.162)\end{array}$ & $\begin{array}{c}0.645^{* * *} \\
(0.240)\end{array}$ & $\begin{array}{c}-0.364^{* * *} \\
(0.130)\end{array}$ & $\begin{array}{c}-0.498^{* * *} \\
(0.157)\end{array}$ & $\begin{array}{c}-0.236^{*} \\
(0.142)\end{array}$ \\
\hline democracy & $\begin{array}{l}-0.580 \\
(0.601)\end{array}$ & $\begin{array}{l}-0.344 \\
(0.657)\end{array}$ & $\begin{array}{c}0.728 \\
(0.586)\end{array}$ & $\begin{array}{c}0.578 \\
(0.735)\end{array}$ & $\begin{array}{c}1.436^{* * *} \\
(0.554)\end{array}$ & $\begin{array}{l}-0.761 \\
(0.638)\end{array}$ & $\begin{array}{l}-0.680 \\
(0.505)\end{array}$ \\
\hline $\begin{array}{l}\text { sponsor }(\text { gov }+\mathrm{dk})^{*} \\
\text { democracy }\end{array}$ & & $\begin{array}{l}-0.439 \\
(0.321)\end{array}$ & $\begin{array}{l}-0.221 \\
(0.287)\end{array}$ & $\begin{array}{l}-0.619 \\
(0.416)\end{array}$ & $\begin{array}{c}0.143 \\
(0.233)\end{array}$ & $\begin{array}{l}0.675^{* *} \\
(0.278)\end{array}$ & $\begin{array}{c}0.156 \\
(0.253)\end{array}$ \\
\hline individual cont. & yes & yes & yes & yes & yes & yes & yes \\
\hline country cont. & yes & yes & yes & yes & yes & yes & yes \\
\hline Constant & $\begin{array}{c}1.535 \\
(1.074)\end{array}$ & $\begin{array}{c}0.408 \\
(0.926)\end{array}$ & $\begin{array}{c}0.959 \\
(1.047)\end{array}$ & $\begin{array}{c}1.370 \\
(1.224)\end{array}$ & $\begin{array}{c}0.346 \\
(1.046)\end{array}$ & $\begin{array}{l}-0.488 \\
(1.071)\end{array}$ & $\begin{array}{c}0.382 \\
(0.964)\end{array}$ \\
\hline Observations & 50,989 & 50,989 & 51,217 & 47,167 & 52,118 & 44,890 & 47,293 \\
\hline Log Likelihood & $-29,865$ & $-29,865$ & $-26,404$ & $-24,065$ & $-30,322$ & $-27,355$ & $-30,704$ \\
\hline
\end{tabular}

Note: Robust standard errors in parentheses. ${ }^{*} p<0.1 ;{ }^{* *} p<0.05 ;{ }^{* * *} p<0.01$ Individual-level controls include: gender, age, rural, discuss politics. Country-level controls include GDP per capita (logged) and corruption 
Table 8: GLMM Regression Results Round 5 (Alternative IV)

\begin{tabular}{|c|c|c|c|c|c|}
\hline & \multicolumn{5}{|c|}{ Dependent variable: } \\
\hline & \multicolumn{2}{|c|}{ trust leader } & \multirow{2}{*}{$\begin{array}{c}\text { trust police } \\
(3)\end{array}$} & \multirow{2}{*}{$\begin{array}{c}\text { country eval } \\
(4)\end{array}$} & \multirow{2}{*}{$\begin{array}{c}\text { trust neighbor } \\
(5)\end{array}$} \\
\hline & $(1)$ & $(2)$ & & & \\
\hline sponsorDK & $\begin{array}{c}0.317^{* * *} \\
(0.024)\end{array}$ & $\begin{array}{c}0.607^{* * *} \\
(0.076)\end{array}$ & $\begin{array}{c}0.600^{* * *} \\
(0.079)\end{array}$ & $\begin{array}{c}0.345^{* * *} \\
(0.067)\end{array}$ & $\begin{array}{c}0.058 \\
(0.065)\end{array}$ \\
\hline democracy & $\begin{array}{c}0.554 \\
(0.708)\end{array}$ & $\begin{array}{c}0.942 \\
(0.716)\end{array}$ & $\begin{array}{l}1.404^{* *} \\
(0.631)\end{array}$ & $\begin{array}{l}1.260^{*} \\
(0.732)\end{array}$ & $\begin{array}{c}0.169 \\
(0.710)\end{array}$ \\
\hline rural & $\begin{array}{c}0.245^{* * *} \\
(0.023)\end{array}$ & $\begin{array}{c}0.248^{* * *} \\
(0.023)\end{array}$ & $\begin{array}{c}0.302^{* * *} \\
(0.025)\end{array}$ & $\begin{array}{c}0.185^{* * *} \\
(0.023)\end{array}$ & $\begin{array}{c}0.336^{* * *} \\
(0.022)\end{array}$ \\
\hline age & $\begin{array}{c}0.007^{* * *} \\
(0.001)\end{array}$ & $\begin{array}{c}0.007^{* * *} \\
(0.001)\end{array}$ & $\begin{array}{c}0.004^{* * *} \\
(0.001)\end{array}$ & $\begin{array}{c}-0.005^{* * *} \\
(0.001)\end{array}$ & $\begin{array}{c}0.008^{* * *} \\
(0.001)\end{array}$ \\
\hline education & $\begin{array}{c}-0.110^{* * *} \\
(0.006)\end{array}$ & $\begin{array}{c}-0.110^{* * *} \\
(0.006)\end{array}$ & $\begin{array}{c}-0.115^{* * *} \\
(0.007)\end{array}$ & $\begin{array}{l}-0.002 \\
(0.006)\end{array}$ & $\begin{array}{c}-0.047^{* * *} \\
(0.006)\end{array}$ \\
\hline female & $\begin{array}{c}-0.073^{* * *} \\
(0.021)\end{array}$ & $\begin{array}{c}-0.072^{* * *} \\
(0.021)\end{array}$ & $\begin{array}{c}-0.056^{* *} \\
(0.022)\end{array}$ & $\begin{array}{c}-0.070^{* * *} \\
(0.020)\end{array}$ & $\begin{array}{c}-0.119^{* * *} \\
(0.020)\end{array}$ \\
\hline discuss pol & $\begin{array}{c}0.062^{* * *} \\
(0.015)\end{array}$ & $\begin{array}{c}0.062^{* * *} \\
(0.015)\end{array}$ & $\begin{array}{l}-0.016 \\
(0.016)\end{array}$ & $\begin{array}{l}0.033^{* *} \\
(0.015)\end{array}$ & $\begin{array}{c}0.006 \\
(0.014)\end{array}$ \\
\hline $\begin{array}{l}\text { sponsorDK* } \\
\text { democracy }\end{array}$ & & $\begin{array}{c}-0.562^{* * *} \\
(0.139)\end{array}$ & $\begin{array}{c}-0.603^{* * *} \\
(0.145)\end{array}$ & $\begin{array}{c}-0.432^{* * *} \\
(0.124)\end{array}$ & $\begin{array}{l}-0.032 \\
(0.124)\end{array}$ \\
\hline Constant & $\begin{array}{c}-1.135^{* * *} \\
(0.393)\end{array}$ & $\begin{array}{c}-1.336^{* * *} \\
(0.397)\end{array}$ & $\begin{array}{c}-1.964^{* * *} \\
(0.347)\end{array}$ & $\begin{array}{l}-0.628 \\
(0.400)\end{array}$ & $\begin{array}{c}0.155 \\
(0.387)\end{array}$ \\
\hline Observations & 47,754 & 47,754 & 49,614 & 46,830 & 50,456 \\
\hline Countries & 33 & 33 & 34 & 34 & 34 \\
\hline
\end{tabular}

Note: $\quad{ }^{*} \mathrm{p}<0.1 ;{ }^{* *} \mathrm{p}<0.05 ;{ }^{* * *} \mathrm{p}<0.01$ 
Table 9: GLMM Regression Results Round 6 (Recoded DV)

\begin{tabular}{|c|c|c|c|c|}
\hline & \multicolumn{4}{|c|}{ Dependent variable } \\
\hline & \multicolumn{2}{|c|}{ trust leader } & \multirow{2}{*}{$\begin{array}{c}\text { trust police } \\
\text { (3) }\end{array}$} & \multirow{2}{*}{$\begin{array}{l}\text { trust ruling party } \\
\qquad(4)\end{array}$} \\
\hline & $(1)$ & (2) & & \\
\hline sponsor & $\begin{array}{c}0.270^{* * *} \\
(0.068)\end{array}$ & $\begin{array}{l}0.484^{* *} \\
(0.214)\end{array}$ & $\begin{array}{l}0.271^{*} \\
(0.145)\end{array}$ & $\begin{array}{c}0.401^{*} \\
(0.216)\end{array}$ \\
\hline democracy & $\begin{array}{l}-0.632 \\
(0.638)\end{array}$ & $\begin{array}{l}-0.488 \\
(0.648)\end{array}$ & $\begin{array}{c}0.160 \\
(0.573)\end{array}$ & $\begin{array}{c}0.279 \\
(0.642)\end{array}$ \\
\hline gdp pc & $\begin{array}{l}-0.062 \\
(0.121)\end{array}$ & $\begin{array}{l}-0.061 \\
(0.122)\end{array}$ & $\begin{array}{c}0.084 \\
(0.113)\end{array}$ & $\begin{array}{l}-0.050 \\
(0.107)\end{array}$ \\
\hline corruption & $\begin{array}{l}-0.113 \\
(1.436)\end{array}$ & & $\begin{array}{l}-2.283^{*} \\
(1.379)\end{array}$ & $\begin{array}{l}-1.720 \\
(1.364)\end{array}$ \\
\hline rural & $\begin{array}{c}0.231^{* * *} \\
(0.023)\end{array}$ & $\begin{array}{c}0.231^{* * *} \\
(0.023)\end{array}$ & $\begin{array}{c}0.316^{* * *} \\
(0.022)\end{array}$ & $\begin{array}{c}0.280^{* * *} \\
(0.023)\end{array}$ \\
\hline age & $\begin{array}{c}0.009^{* * *} \\
(0.001)\end{array}$ & $\begin{array}{c}0.009^{* * *} \\
(0.001)\end{array}$ & $\begin{array}{c}0.004^{* * *} \\
(0.001)\end{array}$ & $\begin{array}{c}0.006^{* * *} \\
(0.001)\end{array}$ \\
\hline education & $\begin{array}{c}-0.030^{* * *} \\
(0.006)\end{array}$ & $\begin{array}{c}-0.030^{* * *} \\
(0.006)\end{array}$ & $\begin{array}{c}-0.061^{* * *} \\
(0.006)\end{array}$ & $\begin{array}{c}-0.056^{* * *} \\
(0.006)\end{array}$ \\
\hline female & $\begin{array}{c}0.023 \\
(0.021)\end{array}$ & $\begin{array}{c}0.023 \\
(0.021)\end{array}$ & $\begin{array}{c}0.022 \\
(0.020)\end{array}$ & $\begin{array}{c}0.078^{* * *} \\
(0.021)\end{array}$ \\
\hline discuss pol & $\begin{array}{l}-0.014 \\
(0.015)\end{array}$ & $\begin{array}{l}-0.014 \\
(0.015)\end{array}$ & $\begin{array}{l}-0.003 \\
(0.015)\end{array}$ & $\begin{array}{c}0.040^{* * *} \\
(0.015)\end{array}$ \\
\hline $\begin{array}{l}\text { sponsor* } \\
\text { democracy }\end{array}$ & & $\begin{array}{l}-0.400 \\
(0.380)\end{array}$ & $\begin{array}{l}-0.252 \\
(0.258)\end{array}$ & $\begin{array}{l}-0.288 \\
(0.374)\end{array}$ \\
\hline Constant & $\begin{array}{c}0.752 \\
(1.211)\end{array}$ & $\begin{array}{c}0.611 \\
(0.917)\end{array}$ & $\begin{array}{c}0.333 \\
(1.165)\end{array}$ & $\begin{array}{c}0.625 \\
(1.081)\end{array}$ \\
\hline $\begin{array}{l}\text { Observations } \\
\text { Log Likelihood }\end{array}$ & $\begin{array}{c}44,442 \\
-27,313.020\end{array}$ & $\begin{array}{c}44,442 \\
-27,312.480\end{array}$ & $\begin{array}{c}44,646 \\
-28,696.310\end{array}$ & $\begin{array}{c}41,212 \\
-26,388.980\end{array}$ \\
\hline
\end{tabular}

